\title{
CFD Analysis of Geothermal Heat Exchanger at Different Orientation
}

\author{
Anand Kumar Patel \\ M.Tech. Scholar \\ NRI Institute of Research \&Technology \\ Bhopal, M.P, India \\ anandkr64@gmail.com
}

\begin{abstract}
The main objective of present work to investigate the arrangements of piping system of earth tube heat exchanger for better thermal comfort. For these work CFD analysis on three different designs of earth tube heat exchanger for summer and winter session for Bhopal location have been performed. computational fluid dynamics analysis have been performed on earth tube heat exchanger using horizontal pipe at various air velocity such as $0.5 \mathrm{~m} / \mathrm{sec}, 1 \mathrm{~m} / \mathrm{sec}$, $2 \mathrm{~m} / \mathrm{sec}, 3 \mathrm{~m} / \mathrm{sec}, 4 \mathrm{~m} / \mathrm{sec} \& 5 \mathrm{~m} / \mathrm{sec}$ for summer session, to get temperature distribution inside the earth tube heat exchanger. Results show that there are drop of temperature in summer session range from $318 \mathrm{~K}$ to $296 \mathrm{~K}$ and rise of temperature in winter session range from $288 \mathrm{~K}$ to $296.7 \mathrm{~K}$. It has been observed from the results of computational fluid dynamic analysis that the earth tube heat exchanger using horizontal pipe gives better result as compared with vertical and inclined piping arrangement. So it is recommended that the earth tube heat exchanger using horizontal pipe arrangement may be used for better thermal comfort.
\end{abstract}

Keywords: Earth tube heat exchanger, Thermal comfort, Temperature distribution, CFD etc.

\section{INTRODUCTION}

A grounding pipe is a set of heat exchanger in which a pipe or pipe is buried to facilitate the transfer of geothermal heat with air. This system uses an almost constant soil temperature to dissipate or dissipate the thermal energy from or to the air inflow into the ground. The ambient air that circulates in the grounding pipes is heated or cooled before entering the building's air system. In summer, the earth is colder than the outside air temperature and the air is cooled as it passes through the pipes. The opposite occurs in winter. As materials for pipes, plastics, metal or concrete can be used. Each type of material has its advantages and disadvantages. This is considered a "passive" renewable energy system because no external mechanical energy is used to produce the heat transfer effect, but only a fan to move the air through the pipe. In general, the temperature

\author{
Pankaj Mishra \\ Assistant Professor \\ NRI Institute of Research \&Technology \\ Bhopal, M.P, India \\ pankajhnmishra@yahoo.com
}

variation of this type of system is insufficient to completely condition the air passages, but is a simple and efficient means of energy for preheating or precooling.

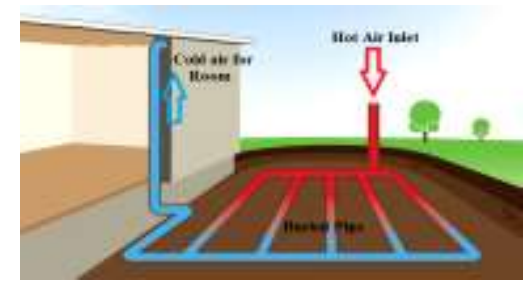

Figure - 1 Schematic diagram of Earth Tube Heat Exchanger In recent years, the cooling of outdoor air by underground pipes has been recognized using a terrestrial heat exchanger (EAHE) to increase building comfort and reduce energy requirements. This is due to one of the most important thermal properties of the earth: at a depth of 1.5-2 m, the soil temperature remains practically the same throughout the year. The internal temperature of the Earth remains higher in winter than the surface temperature of the Earth and vice versa in the summer.

\section{1) Ground Heat Transfer Mechanisms}

The temperature field in the ground is influenced by different dimensions. While the influence of runoff water or geothermal heat is likely to be neglected, it is important to consider incident solar radiation and the exchange of long-wave radiation between the ground and the sky.

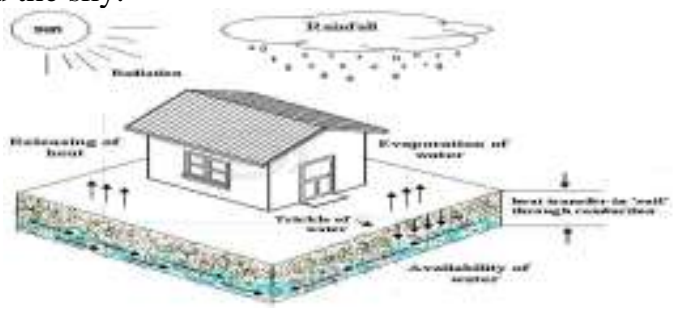

Figure 2 - Different environmental influences and heat transfer mechanisms that influence the temperature field in the Ground [Wagner et al, 2000]

The absorption of solar radiation depends on the ground cover and color, while the loss of radiation from long waves depends on the surface temperature of the soil. The radioactive balance between solar gain and loss of 
long waves is generally positive in summer and negative in winter.

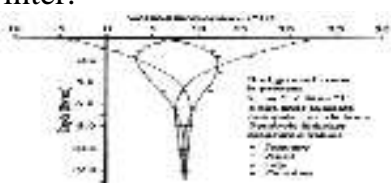

Figure 3- Ground temperature variations as a function of depth. [Carmody, 1985]

\section{LITERATURE REVIEW}

S.H. Hammadi [1] In climates, outdoor hot water supplies are exposed to direct sunlight, in addition to the warm summer breeze. The storage water temperature exceeds $50^{\circ} \mathrm{C}$. To solve this problem, a time-based analysis of a cylindrical tank of hot water exposed to intense sunlight is performed. The analysis includes an energy balance of the water tank and a groundwater heat exchanger that lowers the water temperature during the summer months. The predominant equations are solved numerically with the fourth order Runge-Kutta method. It was found that the use of underground heat exchangers lowered the water temperature by about 16 ${ }^{\circ} \mathrm{C}$. A comparison of the numerical results with the experimental data showed a good agreement.

Namrata Bordoloi at el. [2] Energy saving is an integral part of the current scenario. EAHE heat exchangers are a technique that promotes energy savings. EAHE is an unconventional technique that uses geothermal energy from the earth for heating and cooling. This article gives an overview of the different EAHE combinations. The overview provides a complete summary of previous EAHE activities. In the overview, the analytical and experimental studies of the various EAHE combinations are described in detail and the results of thermal performance are analyzed. It also takes into consideration the environmental aspect of energy saving. It was concluded from the abstract that the design parameters have a direct or indirect influence on the outlet temperature. The result also shows that the pipe material does not have much influence on the outlet temperature. When energy is saved, EAHE technology saves more energy than conventional air conditioning systems. As a result, this technology can effectively reduce greenhouse gases and improve the environment.

Sayeh Menhoudj at el [3] this paper presents a study on the energy efficiency of an air-to-ground heat exchanger (EAHE) for buildings located in the Maghreb climate context (Oran, Béchar and Aurar in Algeria). To verify the influence of the material, two air ducts (one in galvanized plate and the other in PVC) are considered in the same geometric conditions $(20 \mathrm{~m}$ cable with $120 \mathrm{~mm}$ diameter and $2 \mathrm{~m}$ mounting depth). They are used separately to ventilate two adjacent rooms that form a test cell located on the IGCMOUSTOMB campus (Oran, Algeria). An experimental unit has been set up to measure the temperature at different points (air inlet / outlet). The measurements were made in August 2015.

Lazaros Aresti, Paul Christodoulidesb \& Georgios Florides [4] Advances in technology and renewable energy systems have evolved considerably over the years. Geothermal energy was introduced in Italy in 1904 and since then has greatly increased its efficiency. Geothermal heat pumps (GSHP), one of the main types of RES, are used in combination with geothermal heat exchangers (GHE) to heat and cool a room. Geothermal energy extracts heat from the earth through a network of pipes. The closed circuit system (vertical or horizontal) is the most common configuration. Pipes can also use natural underground wells in an open circuit. GHEs offer much better performance than traditional air-to-air heat exchanger systems. Reducing their costs and improving their overall efficiency through their design is essential for research.

\section{III.OBJECTIVE}

The main objectives of the present work are as follows:

1. To study the various literatures to investigate the research and development status of this technique about earth tube heat exchanger system.

2. To Perform Computational fluid dynamics analysis of different models at different velocity of earth tube heat exchanger for Bhopal climate.

3. To finding out the variation in outlet air temperature with different velocity rate.

\section{IV.METHODOLOGY}

1) The soil around the heat exchanger is homogenous.

2) Soil conductivity along vertical and horizontal directions is constant.

3) Flow of air is uniform along the length of the pipes.

4) It is assumed that the soil properties are isotropic and there is perfect contact between the soil and the pipe.

\section{1) Mathematical Analysis:}

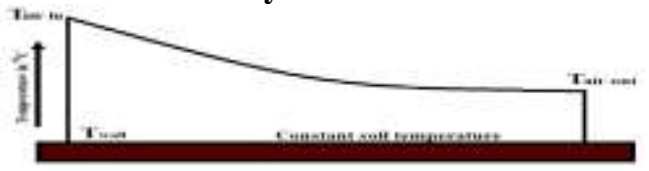

Reynolds number and prandtl number inside the pipe:

$$
\begin{aligned}
& R_{e}=\frac{V_{\text {air }} \times D_{i}}{v} \\
& P_{r}=\frac{\rho \times v \times C_{p}}{k}
\end{aligned}
$$

Heat transfer along the pipe can be calculated as $\emptyset=\dot{m} \times C_{p f} \times d T(x)=\frac{d x}{R_{\text {con }}+R_{\text {pipe }}+R_{\text {soil }}} \times(T(z, x)-T(x))$

Where

Convective thermal resistance between the internal surface of the pipe and air in the pipe $R_{\text {con }}=$ Convective thermal resistance between the internal surface of the pipe and air in the pipe

$$
\begin{gathered}
R_{\text {con }}=\frac{1}{r_{i} \times h_{\text {con }} \times 2 \pi} \\
h_{\text {con }}=\frac{N_{u} \times K}{D} \\
N_{u}=0.0214 \times\left(R_{e}{ }^{0.8}-100\right) \times p_{r}{ }^{0.4} \\
R_{\text {pipe }}=\text { Thermal resistance of pipe } \\
R_{\text {pipe }}=\frac{1}{K_{\text {pipe }} \times 2 \pi} \times \ln \left(\frac{r_{e}}{r_{i}}\right) \\
R_{\text {soil }}=\text { Thermal resistance of soil }
\end{gathered}
$$




$$
R_{\text {soil }}=\frac{1}{K \times 2 \pi} \times \ln \left(\frac{R(z, t)}{r_{e}}\right)
$$

Total thermal conductance of earth tube heat exchanger:

$$
\begin{gathered}
m_{1}=\rho A V \\
1.2699 \times \frac{\pi}{4} \times 0.0595^{2} \times 5 \\
=0.01904 \mathrm{~m} / \mathrm{s} .
\end{gathered}
$$$$
G_{\text {total }}=\frac{1}{R_{\text {con }}+R_{\text {pipe }}+R_{\text {soil }}}
$$

Mass flow rate through pipe

Reynold'snumber :

$$
\begin{gathered}
R_{e}=\frac{\rho V D}{\mu} \\
R_{e}=\frac{V D}{\vartheta} \\
4 \times 0.079 \\
\frac{16.96 \times 10^{-6}}{=} 18632.075
\end{gathered}
$$

Since $\vartheta=\frac{\mu}{\rho}$

$\operatorname{Re}>10000$

Therefore, value of convective heat transfer coefficient inside the pipe is calculated by using Dittus-Boelter equation. The Dittus-Bolter equation for turbulent flow is an explicit function for calculating the nusselt number. It is easy to solve but is less accurate when there is a large temperature difference across the fluid. The Dittus-Bolter equation is :-

$$
\begin{aligned}
& \qquad N_{u}=0.023 \times\left(R_{e}\right)^{\frac{4}{5}} \times P_{r}^{n} \\
& \text { Nuselt number }\left(N_{u}\right)=\frac{\text { convective heat transfer }}{\text { conductive heat transfer }}
\end{aligned}
$$$$
\text { Mathematically, } \mathrm{N}_{\mathrm{u}}=\frac{\mathrm{hD}}{\mathrm{K}}
$$

2) Value of convective heat transfer coefficient inside the pipe

$\mathrm{h}_{\mathrm{i}}$ - convective heat transfer coefficient inside the pipe

$$
\begin{aligned}
N_{u} & =0.023 \times\left(R_{e}\right)^{\frac{4}{5}} \times P_{r}{ }^{n} \\
\frac{h_{i} D_{i}}{K_{a}} & =0.023 \times\left(R_{e}\right)^{\frac{4}{5}} \times P_{r}{ }^{0.4}
\end{aligned}
$$

$$
\begin{gathered}
\quad \ldots . .(\mathrm{n}=0.4 \text { for he } \\
\frac{h_{i} \times 0.0595}{0.024458}=0.023 \times(23323.58)^{\frac{4}{5}} \times 0.71866^{0.4} \\
\mathrm{~h}_{\mathrm{i}}=25.849 \mathrm{~W} / \mathrm{m}^{2} \mathrm{~K}
\end{gathered}
$$

convective heat transfer coefficient outside the pipe

$$
\begin{gathered}
\mathrm{h}_{\mathrm{o}}=5.7+3.8 \mathrm{u} \\
\mathrm{h}_{\mathrm{o}}=5.7+(3.8 \times 3.42)
\end{gathered}
$$

(Annual average wind velocity in Bhopal is $3.42 \mathrm{~m} / \mathrm{sec}$ )

$$
\mathrm{H}_{\mathrm{o}}=18.696 \mathrm{~W} / \mathrm{m}^{2} \mathrm{~K}
$$

Now, overall heat transfer coefficient $\left(\mathrm{U}_{\mathrm{i}}\right)$ for winter is taken because heat is transfer from outside to inside of the pipe.

\section{3) Heat Transfer Rate $(Q)$ :}

$$
\begin{gathered}
\frac{1}{\mathrm{U}_{\mathrm{i}}}=\frac{1}{\mathrm{~h}_{\mathrm{i}}}+\frac{\mathrm{R}_{1}}{\mathrm{~K}_{\mathrm{a}}} \ln \left(\frac{\mathrm{R}_{2}}{\mathrm{R}_{1}}\right)+\frac{1}{\mathrm{~h}_{\mathrm{o}}}\left(\frac{\mathrm{R}_{1}}{\mathrm{R}_{2}}\right) \\
\mathrm{U}_{\mathrm{i}}=\mathrm{W} / \mathrm{m}^{2} \mathrm{~K}
\end{gathered}
$$

$$
\begin{gathered}
Q=\frac{\mathrm{dt}}{\mathrm{R}_{\text {th }}} \\
\mathrm{R}_{\text {th }}=\frac{1}{\mathrm{~h}_{\mathrm{i}} \mathrm{A}_{\mathrm{i}}}+\frac{1}{2 \pi \mathrm{K}_{\mathrm{s}} \mathrm{l}} \ln \left(\frac{\mathrm{R}_{2}}{\mathrm{R}_{1}}\right)+\frac{1}{\mathrm{~h}_{\mathrm{o}} \mathrm{A}_{\mathrm{o}}} \\
\mathrm{R}_{\mathrm{th}}=\frac{1}{\mathrm{~h}_{\mathrm{i}} 2 \pi \mathrm{R}_{1} \mathrm{l}}+\frac{1}{2 \pi \mathrm{K}_{\mathrm{s}} \mathrm{l}} \ln \left(\frac{\mathrm{R}_{2}}{\mathrm{R}_{1}}\right)+\frac{1}{\mathrm{~h}_{\mathrm{o}} 2 \pi \mathrm{R}_{2} \mathrm{l}} \\
\mathrm{R}_{\mathrm{th}}=\frac{1}{2 \pi \mathrm{l}}\left\{\frac{1}{\mathrm{~h}_{\mathrm{i}} \mathrm{R}_{1}}+\frac{1}{\mathrm{~K}_{\mathrm{s}}} \ln \left(\frac{\mathrm{R}_{2}}{\mathrm{R}_{1}}\right)+\frac{1}{\mathrm{~h}_{\mathrm{o}} \mathrm{R}_{2}}\right\} \\
\mathrm{Q}=\frac{\mathrm{dt}}{\mathrm{R}_{\mathrm{th}}}
\end{gathered}
$$

$$
\mathrm{Q}=\frac{\mathrm{T}_{\mathrm{r} 1}-\mathrm{T}_{\mathrm{a}}}{\mathrm{R}_{\mathrm{th}}}
$$

4) Algorithm used for Computational fluid dynamics analysis:

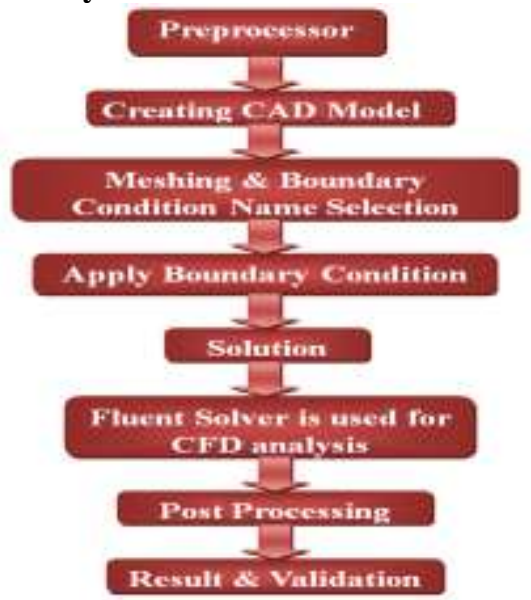

Figure 5: Algorithm used for Computational fluid dynamics analysis

5) Governing Equations:

The following considerations were made for the mathematical model:

- Steady state flow

- Boussinesq model

- $\quad$ k-epsilon turbulence model

6) Conservation of mass or continuity equation: The equation for conservation of mass, or continuity equation, can be written as follows:

$$
\frac{\partial \rho}{\partial t}+\nabla \cdot(\rho \vec{v})=S_{m}
$$

Where $S_{m}=$ mass added to the continuous phase or any user defined sources.

For 2D axisymmetric geometries, the continuity

equation is given by

$$
\frac{\partial \rho}{\partial t}+\frac{\partial}{\partial x}\left(\rho v_{x}\right)+\frac{\partial}{\partial r}\left(\rho v_{r}\right)+\frac{\rho v_{r}}{r}=S_{m}
$$

Where $x$ is the axial coordinate, $r$ is the radial coordinate, $v_{x}$ is the axial velocity, and $v_{r}$ is the radial velocity.

\section{7) Momentum Conservation Equations}

Conservation of momentum in an inertial reference frame is described by

$$
\frac{\partial}{\partial t}(\rho \vec{v})+\nabla \cdot(\rho \vec{v} \vec{v})=-\nabla p+\nabla \cdot(\overline{\bar{\tau}})+\rho \vec{g}+\vec{F}
$$

Where $\mathrm{p}=$ static pressure

$\overline{\bar{\tau}}=$ stress tensor,

$\rho \vec{g}=$ gravitational body force and

$\vec{F}=$ external body forces

The stress tensor $\overline{\bar{\tau}}$ is given by

$$
\overline{\bar{\tau}}=\mu\left[\left(\nabla \vec{v}+\nabla \vec{v}^{\mathrm{T}}\right)-\frac{2}{3} \nabla \cdot \vec{v} I\right]
$$

where $\mu=$ molecular viscosity

$I=$ unit tensor,

For 2D axisymmetric geometries, the axial and radial momentum conservation equations are given by 


$$
\begin{aligned}
& \qquad \begin{aligned}
\frac{\partial}{\partial x}\left(\rho v_{x}\right)+\frac{1}{r} \frac{\partial}{\partial x}\left(r \rho v_{x} v_{x}\right) & +\frac{1}{r} \frac{\partial}{\partial r}\left(r \rho v_{r} v_{r}\right) \\
& =-\frac{\partial p}{\partial x}+\frac{1}{r} \frac{\partial}{\partial x}\left[r \mu\left(2 \frac{\partial v_{x}}{\partial x}-\frac{2}{3}(\nabla \cdot \vec{v})\right)\right] \\
& +\frac{1}{r} \frac{\partial}{\partial r}\left[r \mu\left(\frac{\partial v_{x}}{\partial r}+\frac{\partial v_{r}}{\partial x}\right)\right]+F_{x}
\end{aligned} \\
& \text { And } \\
& \qquad \begin{aligned}
& \frac{\partial}{\partial t}\left(\rho v_{r}\right)+\frac{1}{r} \frac{\partial}{\partial x}\left(r \rho v_{x} v_{r}\right)+\frac{1}{r} \frac{\partial}{\partial r}\left(r \rho v_{r} v_{r}\right) \\
&=-\frac{\partial p}{\partial r}+\frac{1}{r} \frac{\partial}{\partial x}\left[r \mu\left(\frac{\partial v_{r}}{\partial x}+\frac{\partial v_{x}}{\partial r}\right)\right] \\
&+\frac{1}{r} \frac{\partial}{\partial r}\left[r \mu\left(2 \frac{\partial v_{r}}{\partial r}-\frac{2}{3}(\nabla \cdot \vec{v})\right)\right]-2 \mu \frac{v_{r}}{r^{2}} \\
&+\frac{2 \mu}{3 r}(\nabla \cdot \vec{v})+\rho \frac{v_{z}^{2}}{r}+F_{r}
\end{aligned}
\end{aligned}
$$

Where

$$
\nabla . \vec{v}=\frac{\partial v_{x}}{\partial x}+\frac{\partial v_{r}}{\partial r}+\frac{v_{r}}{r}
$$

Where $v_{x}=$ Axial velocity

$v_{r}=$ Radial velocity

$v_{z}=$ swirl velocity

\section{8) Energy Equation}

The energy equation for the mixture takes the following form:

$$
\frac{\partial}{\partial t} \sum_{k=1}^{n}\left(\alpha_{k} \rho_{k} E_{k}\right)+\nabla \cdot \sum_{k=1}^{n}\left(\alpha_{k} \vec{v}_{k}\left(\rho_{k} E_{k}+p\right)\right)=\nabla \cdot\left(k_{e f f} \nabla T\right)+S_{E}
$$

where $k_{\text {eff }}=$ effective conductivity

$S_{E}=$ volumetric heat sources

Where

$$
E_{k}=h_{k}-\frac{p}{\rho k}+\frac{v_{k}^{2}}{2}
$$

$E_{k}=h_{k}$ for an incompressible phase and $h_{k}=$ sensible enthalpy for phase $k$

$\boldsymbol{k}-\in$ model

The turbulence kinetic energy, $k$, and its rate of dissipation, $\in$, are obtained from the following transport equations:

$$
\begin{aligned}
& \qquad \begin{aligned}
\frac{\partial}{\partial t}(\rho k)+\frac{\partial}{\partial x_{i}}\left(\rho k v_{i}\right) & =\frac{\partial}{\partial x_{j}}\left[\left(\mu+\frac{\mu_{t}}{\sigma_{k}}\right) \frac{\partial k}{\partial x_{j}}\right]+G_{k}+G_{b}-\rho \\
& \in-Y_{M}+S_{k}
\end{aligned} \\
& \text { and } \begin{aligned}
\frac{\partial}{\partial t}(\rho \in)+\frac{\partial}{\partial x_{i}}\left(\rho \in v_{i}\right) \\
=\frac{\partial}{\partial x_{j}}\left[\left(\mu+\frac{\mu_{t}}{\sigma_{\epsilon}}\right) \frac{\partial \in}{\partial x_{j}}\right]+C_{1 \in} \frac{\epsilon}{k}\left(G_{k}+C_{3 \in} G_{b}\right) \\
-C_{2 \in} \rho \frac{\epsilon^{2}}{k}+S_{\epsilon}
\end{aligned}
\end{aligned}
$$

$G_{b}$ is the generation of turbulence kinetic energy due to buoyancy,

$Y_{M}$ represents the contribution of the fluctuating dilatation in compressible turbulence to the overall dissipation rate,

$C_{1 \in}, C_{2 \in}$, and $C_{3 \in}$ are constant.

$\sigma_{k}$ and $\sigma_{\in}$ are turbulent Prandtl numbers for $\mathrm{k}$ and $\epsilon$,

$S_{k}$ And $S_{\in}$ are user-defined source terms.

9) CFD analysis of Earth tube heat exchanger using horizontal pipe

\section{CAD Modeling:}

In this paper, a two-dimensional CAD model of a horizontal tube heat exchanger with horizontal tubes was created using the ANSYS Workbench modular design. the outer and inner diameters of the tube are 80 $\mathrm{mm}$ and $78 \mathrm{~mm}$ respectively and its total length is $50 \mathrm{~m}$.
A two-dimensional view of the ground tube heat exchanger with horizontal pipe is shown in figure no.

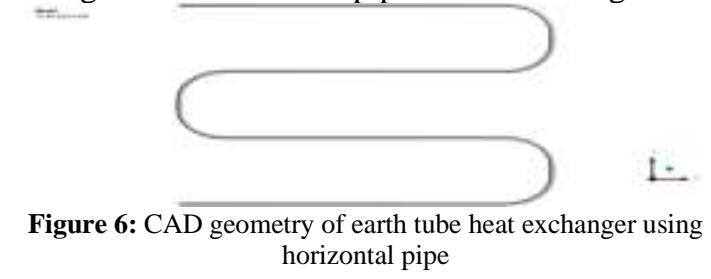

Meshing: Once the CAD geometry is complete, the horizontal tube geothermal heat exchanger is imported into the ANSYS work bench for further fluid flow analysis. The next step is a mesh. Networking is a critical process in analyzing finite elements in this process. The geometry of the CAD is divided into a large number of small parts called mesh. The total number of nodes generated in this job is 104832 and the total number of elements is 84195 . The types of elements used are Hex8, which have a hexagonal shape with eight nodes on each element.

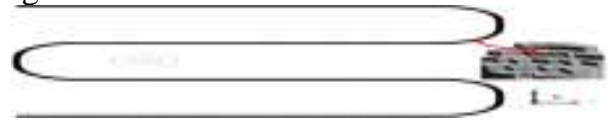

Figure 7: Meshing of earth tube heat exchanger using horizontal pipe

10) Factor that affect the mesh quality:

- Rate of convergence: if the mesh quality is good the rate of convergence will be grater which means the correct solution can be achieved faster.

- Solution precision: A better mesh quality provides a more precise solution.

- Computational processing time required: for the highly refined mesh the computational time will be relatively large.

- Grid Independence result: Once the computations are done and the desired property of fluid does not vary with respect to different mesh elements then it represents that further change in elements doesn't vary the results this term known as Independent Grid.

11) Defining Material Properties: For any kind of analysis material property are the main things which must be defined before moving further analysis. There are thousands of materials available in the ANSYS environment or library, if required materials are not available in ANSYS material directory, new material directory also can be created as per requirement. The working fluid is taken as air flowing inside earth tube heat exchanger having density of $1.22 \mathrm{~kg} / \mathrm{m} 3$, specific heat $=1006.43 \mathrm{~J} / \mathrm{kg}-\mathrm{k}$, thermal conductivity $=0.24$ $\mathrm{w} / \mathrm{m}-\mathrm{k}$ and The pipe material of earth tube heat exchanger is taken as steel having density of 8030 $\mathrm{kg} / \mathrm{m} 3$, specific heat $=502.48 \mathrm{~J} / \mathrm{kg}-\mathrm{k}$ and thermal conductivity $=16.27 \mathrm{w} / \mathrm{m}-\mathrm{k}$.

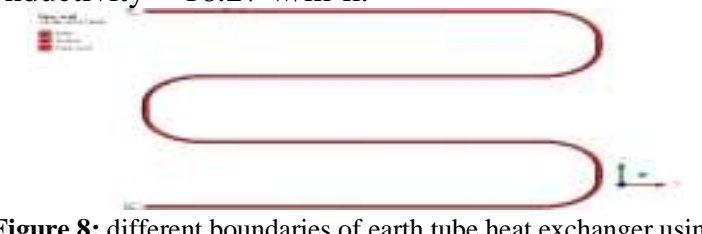

Figure 8: different boundaries of earth tube heat exchanger using horizontal pipe 


\section{2) Boundary condition:}

To determine the temperature distribution inside the earth tube heat exchanger need to on energy equation.

1. Defining of material property, set working fluid as air flowing inside the earth tube heat exchanger and wall of pipe steel with thermal conductivity of 0.6 $\mathrm{W} / \mathrm{m}^{-} \mathrm{K} \& 16.27 \mathrm{~W} / \mathrm{m}^{-} \mathrm{K}$ respectively.

2. For the outlet boundary condition the gauge pressure needs to be set as zero because the flow of air inside the earth tube heat exchanger is atmospheric.

3. Different velocity of air is used for performing CFD analysis ranging from 0.5 to $5 \mathrm{~m} / \mathrm{sec}$.

4. The Fluent solver is used for computational fluid dynamic analysis.

13) Computational fluid dynamics analysis for of earth tube heat exchanger using horizontal pipe at velocity of $0.5 \mathrm{~m} / \mathrm{sec}$ for summer session:

The temperature drop from $318 \mathrm{~K}$ to $296 \mathrm{~K}$ has been recorded and the temperature difference of 22 degree has been observed.
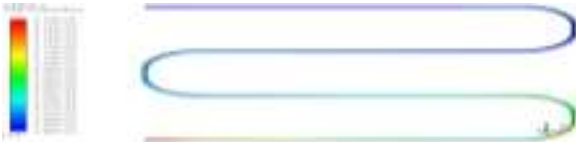

Figure 9: Temperature distribution inside the earth tube heat exchanger using horizontal pipe at velocity of $0.5 \mathrm{~m} / \mathrm{sec}$ for summer session
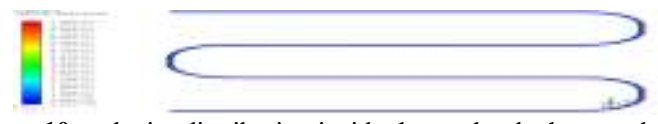

Figure 10: velocity distribution inside the earth tube heat exchanger using horizontal pipe at velocity of $0.5 \mathrm{~m} / \mathrm{sec}$ for summer session

The maximum velocity of $0.728 \mathrm{~m} / \mathrm{sec}$ has been recorded.
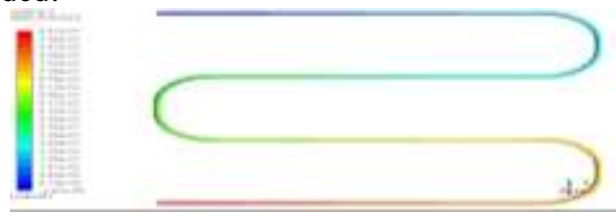

Figure 11: pressure distribution inside the earth tube heat exchanger using horizontal pipe at velocity of $0.5 \mathrm{~m} / \mathrm{sec}$ for summer session

The maximum pressure inside the earth tube heat exchanger for summer session is $0.94 \mathrm{~Pa}$ has been recorded.

14) Computational fluid dynamics analysis for of earth tube heat exchanger using horizontal pipe at velocity of $0.5 \mathrm{~m} / \mathrm{sec}$ for winter session:
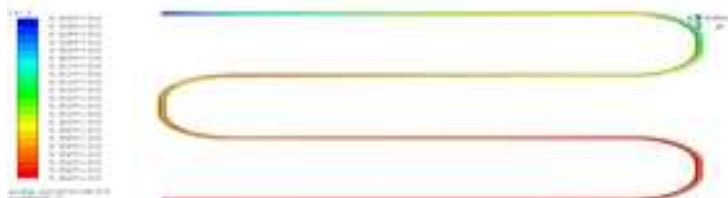

Figure 12: Temperature distribution inside the earth tube heat exchanger using horizontal pipe at velocity of $0.5 \mathrm{~m} / \mathrm{sec}$ for winter session

The temperature increase from $288 \mathrm{~K}$ to $296 \mathrm{~K}$ has been recorded and the temperature difference of 08 degree has been observed.
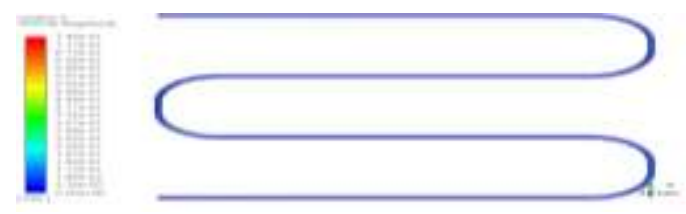

Figure 13: Velocity distribution inside the earth tube heat exchanger using horizontal pipe at velocity of $0.5 \mathrm{~m} / \mathrm{sec}$ for winter session The maximum velocity of $0.748 \mathrm{~m} / \mathrm{sec}$ has been recorded.
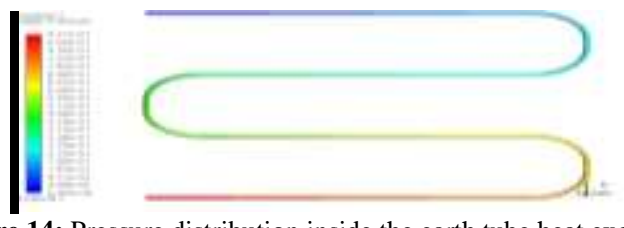

Figure 14: Pressure distribution inside the earth tube heat exchanger using horizontal pipe at velocity of $0.5 \mathrm{~m} / \mathrm{sec}$ for winter session

The maximum pressure inside the earth tube heat exchanger for summer session is $0.931 \mathrm{~Pa}$ has been recorded.

15) Computational fluid dynamics analysis for of earth tube heat exchanger using horizontal pipe at velocity of $1 \mathrm{~m} / \mathrm{sec}$ for summer session:

The temperature drop from $318 \mathrm{~K}$ to $297.1 \mathrm{~K}$ has been recorded and the temperature difference of 20.9 degree has been observed.
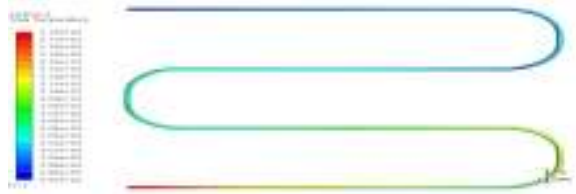

Figure 15: Temperature distribution inside the earth tube heat exchanger using horizontal pipe at velocity of $1 \mathrm{~m} / \mathrm{sec}$ for summer session

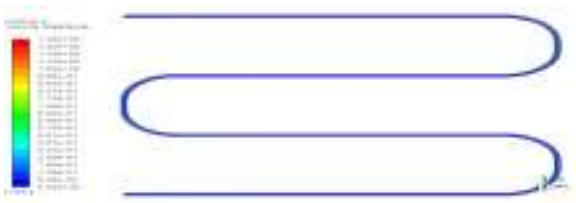

Figure 16: velocity distribution inside the earth tube heat exchanger using horizontal pipe at velocity of $1 \mathrm{~m} / \mathrm{sec}$ for summer session The maximum velocity of $1.29 \mathrm{~m} / \mathrm{sec}$ has been recorded.

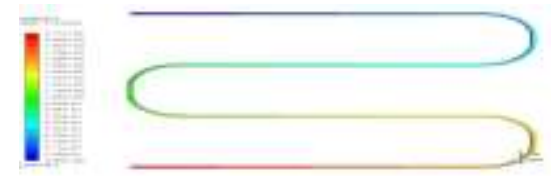

Figure 17: pressure distribution inside the earth tube heat exchanger using horizontal pipe at velocity of $1 \mathrm{~m} / \mathrm{sec}$ for summer session

16) Computational fluid dynamics analysis for of earth tube heat exchanger using horizontal pipe at velocity of $1 \mathrm{~m} / \mathrm{sec}$ for winter session:

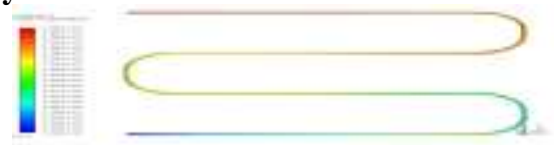

Figure 18: velocity of $1 \mathrm{~m} / \mathrm{sec}$ for winter session

The temperature increase from $288 \mathrm{~K}$ to $295.8 \mathrm{~K}$ has been recorded and the temperature difference of 7.1 degree has been observed. 


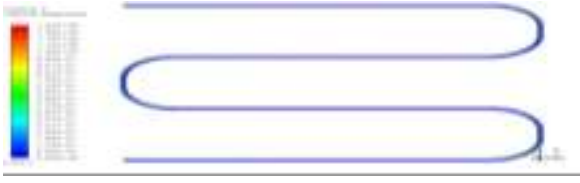

Figure 19: Velocity distribution inside the earth tube heat exchanger using horizontal pipe at velocity of $1 \mathrm{~m} / \mathrm{sec}$ for winter session

The maximum velocity of $1.32 \mathrm{~m} / \mathrm{sec}$ has been recorded.
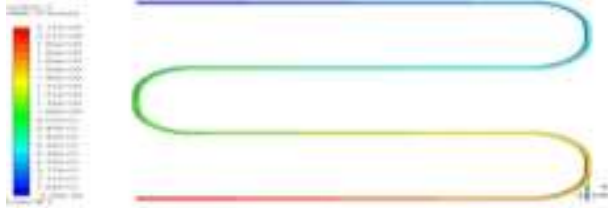

Figure 20: Pressure distribution inside the earth tube heat exchanger using horizontal pipe at velocity of $1 \mathrm{~m} / \mathrm{sec}$ for winter session

The maximum pressure inside the earth tube heat exchanger for summer session is $2.12 \mathrm{~Pa}$ has been recorded.

17) Computational fluid dynamics analysis for of earth tube heat exchanger using horizontal pipe at velocity of $2 \mathrm{~m} / \mathrm{sec}$ for summer session:

The temperature drop from $318 \mathrm{~K}$ to $299.7 \mathrm{~K}$ has been recorded and the temperature difference of 18.3 degree has been observed.
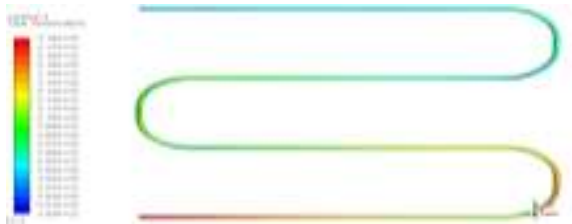

Figure 21: Temperature distribution inside the earth tube heat exchanger using horizontal pipe at velocity of $2 \mathrm{~m} / \mathrm{sec}$ for summer session

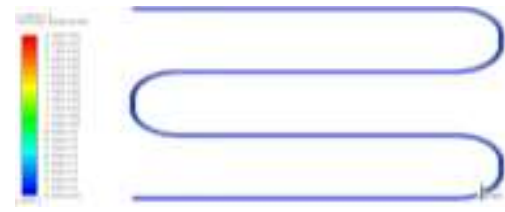

Figure 22: velocity distribution inside the earth tube heat exchange using horizontal pipe at velocity of $2 \mathrm{~m} / \mathrm{sec}$ for summer session

The maximum velocity of $2.4 \mathrm{~m} / \mathrm{sec}$ has been recorded.

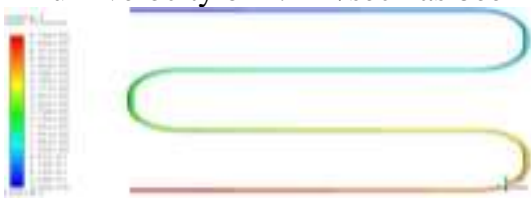

Figure 23: pressure distribution inside the earth tube heat exchange using horizontal pipe at velocity of $2 \mathrm{~m} / \mathrm{sec}$ for summer session

The maximum pressure inside the earth tube heat exchanger for summer session is $4.78 \mathrm{~Pa}$ has been recorded.

18) Computational fluid dynamics analysis for of earth tube heat exchanger using horizontal pipe at velocity of $2 \mathrm{~m} / \mathrm{sec}$ for winter session:

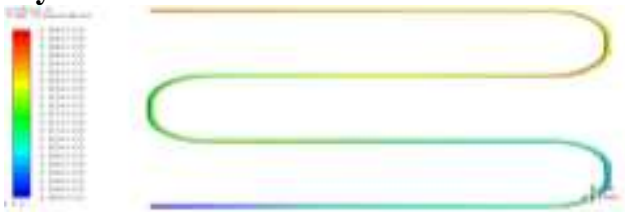

Figure24 : Temperature distribution inside the earth tube heat exchanger using horizontal pipe at velocity of $2 \mathrm{~m} / \mathrm{sec}$ for winter session

The temperature increase from $288 \mathrm{~K}$ to $294.8 \mathrm{~K}$ has been recorded and the temperature difference of 6.8 degree has been observed.

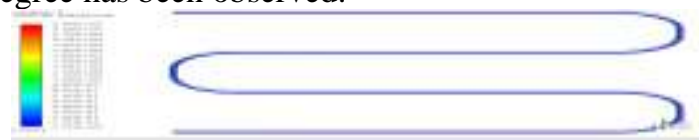

Figure25 : Velocity distribution inside the earth tube heat exchanger using horizontal pipe at velocity of $2 \mathrm{~m} / \mathrm{sec}$ for winter session

The maximum velocity of $2.4 \mathrm{~m} / \mathrm{sec}$ has been recorded.

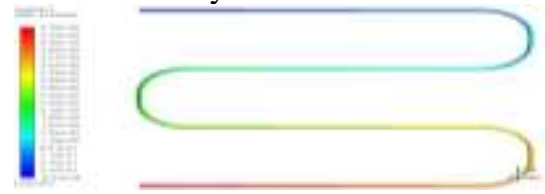

Figure 26: Pressure distribution inside the earth tube heat exchanger using horizontal pipe at velocity of $2 \mathrm{~m} / \mathrm{sec}$ for winter session

The maximum pressure inside the earth tube heat exchanger for summer session is $4.75 \mathrm{~Pa}$ has been recorded.

19) Computational fluid dynamics analysis for of earth tube heat exchanger using horizontal pipe at velocity of $3 \mathrm{~m} / \mathrm{sec}$ for summer session:

The temperature drop from $318 \mathrm{~K}$ to $302.1 \mathrm{~K}$ has been recorded and the temperature difference of 15.9 degree has been observed.

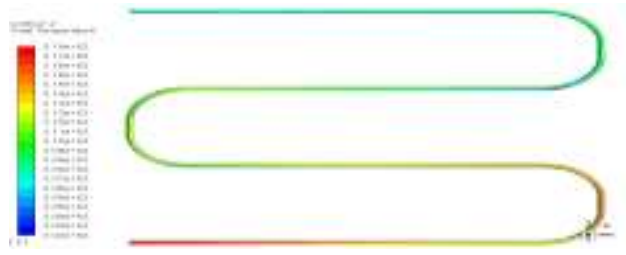

Figure 27: Temperature distribution inside the earth tube heat exchanger using horizontal pipe at velocity of $3 \mathrm{~m} / \mathrm{sec}$ for summer

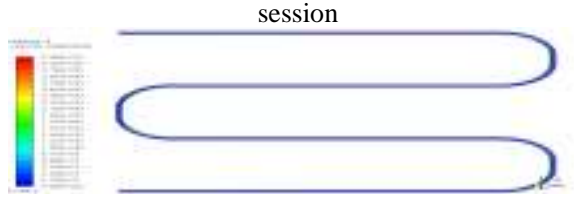

Figure 28: velocity distribution inside the earth tube heat exchanger using horizontal pipe at velocity of $3 \mathrm{~m} / \mathrm{sec}$ for summer session The maximum velocity of $3.49 \mathrm{~m} / \mathrm{sec}$ has been recorded.

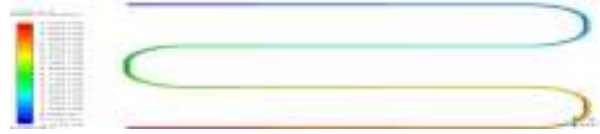

Figure 29: pressure distribution inside the earth tube heat exchanger using horizontal pipe at velocity of $3 \mathrm{~m} / \mathrm{sec}$ for summer session

The maximum pressure inside the earth tube heat exchanger for summer session is $8.34 \mathrm{~Pa}$ has been recorded.

20) Computational fluid dynamics analysis for of earth tube heat exchanger using horizontal pipe at velocity of $3 \mathrm{~m} / \mathrm{sec}$ for winter session:

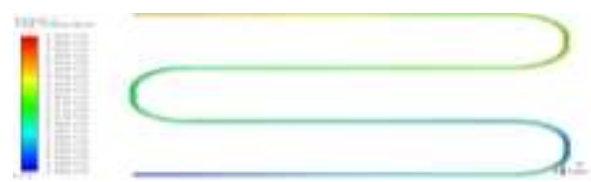


Figure 30: Temperature distribution inside the earth tube heat exchanger using horizontal pipe at velocity of $3 \mathrm{~m} / \mathrm{sec}$ for winter session

The temperature increase from $288 \mathrm{~K}$ to $294.6 \mathrm{~K}$ has been recorded and the temperature difference of 6.6 degree has been observed.
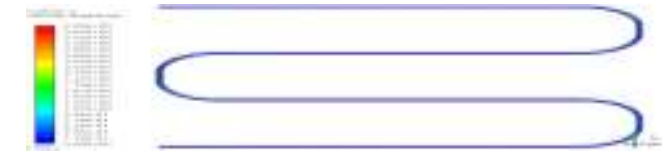

Figure 31: Velocity distribution inside the earth tube heat exchanger using horizontal pipe at velocity of $3 \mathrm{~m} / \mathrm{sec}$ for winter session

The maximum velocity of $3.58 \mathrm{~m} / \mathrm{sec}$ has been recorded.
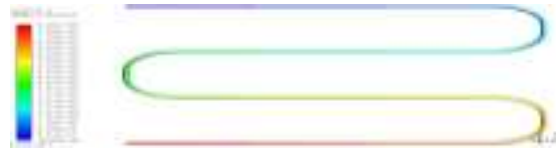

Figure 32: Pressure distribution inside the earth tube heat exchanger using horizontal pipe at velocity of $3 \mathrm{~m} / \mathrm{sec}$ for winter session

The maximum pressure inside the earth tube heat exchanger for summer session is $8.03 \mathrm{~Pa}$ has been recorded.

21) Computational fluid dynamics analysis for of earth tube heat exchanger using horizontal pipe at velocity of $4 \mathrm{~m} / \mathrm{sec}$ for summer session:

The temperature drop from $318 \mathrm{~K}$ to $302.5 \mathrm{~K}$ has been recorded and the temperature difference of 15.5 degree has been observed.
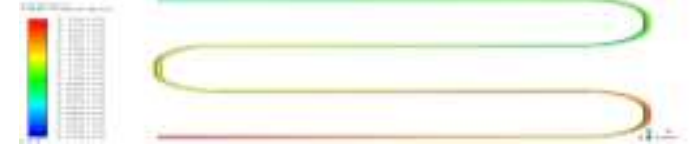

Figure 33: Temperature distribution inside the earth tube heat exchanger using horizontal pipe at velocity of $4 \mathrm{~m} / \mathrm{sec}$ for summer

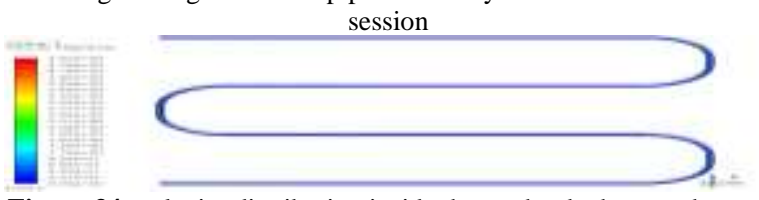

Figure 34: velocity distribution inside the earth tube heat exchange using horizontal pipe at velocity of $4 \mathrm{~m} / \mathrm{sec}$ for summer session

The computational fluid dynamics analysis has been performed on earth tube heat exchanger using horizontal pipe at velocity of $4 \mathrm{~m} / \mathrm{sec}$ for summer session, to get velocity distribution inside the earth tube heat exchanger. The maximum velocity of $4.62 \mathrm{~m} / \mathrm{sec}$ has been recorded.
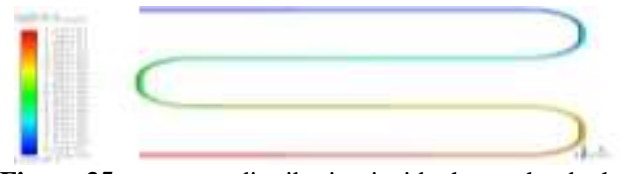

Figure 35 : pressure distribution inside the earth tube heat exchanger using horizontal pipe at velocity of $4 \mathrm{~m} / \mathrm{sec}$ for summer session

The maximum pressure inside the earth tube heat exchanger for summer session is $12.06 \mathrm{~Pa}$ has been recorded.

22) Computational fluid dynamics analysis for of earth tube heat exchanger using horizontal pipe at velocity of $4 \mathrm{~m} / \mathrm{sec}$ for winter session:

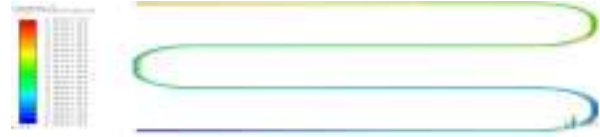

Figure 36: Temperature distribution inside the earth tube heat exchanger using horizontal pipe at velocity of $4 \mathrm{~m} / \mathrm{sec}$ for winter session

The temperature increase from $288 \mathrm{~K}$ to $293.2 \mathrm{~K}$ has been recorded and the temperature difference of 5.2 degree has been observed.

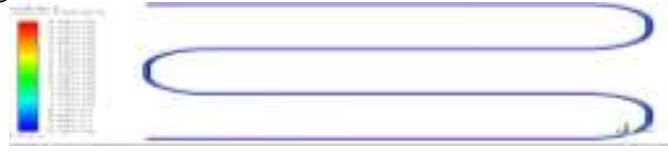

Figure 37: Velocity distribution inside the earth tube heat exchanger using horizontal pipe at velocity of $4 \mathrm{~m} / \mathrm{sec}$ for winter session The maximum velocity of $4.56 \mathrm{~m} / \mathrm{sec}$ has been recorded.

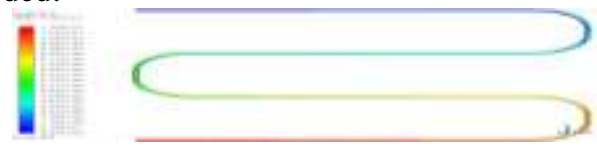

Figure 38: Pressure distribution inside the earth tube heat exchanger using horizontal pipe at velocity of $4 \mathrm{~m} / \mathrm{sec}$ for winter session

23) Computational fluid dynamics analysis for of earth tube heat exchanger using horizontal pipe at velocity of $5 \mathrm{~m} / \mathrm{sec}$ for summer session:

The temperature drop from $318 \mathrm{~K}$ to $305 \mathrm{~K}$ has been recorded and the temperature difference of 13 degree has been observed.

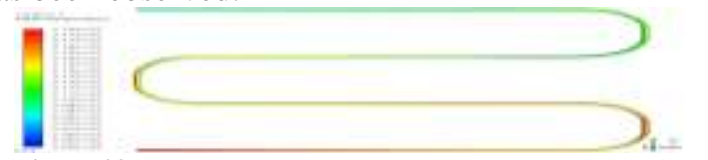

Figure 39: Temperature distribution inside the earth tube heat exchanger using horizontal pipe at velocity of $5 \mathrm{~m} / \mathrm{sec}$ for summer

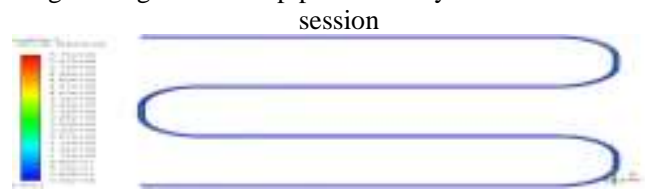

Figure 40: velocity distribution inside the earth tube heat exchanger using horizontal pipe at velocity of $5 \mathrm{~m} / \mathrm{sec}$ for summer session The maximum velocity of $5.75 \mathrm{~m} / \mathrm{sec}$ has been recorded.

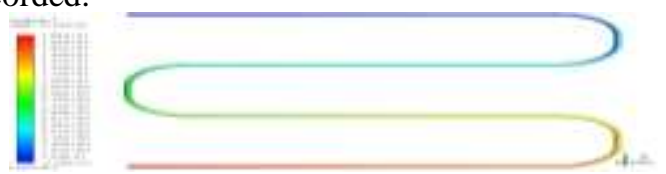

Figure 41: pressure distribution inside the earth tube heat exchanger using horizontal pipe at velocity of $5 \mathrm{~m} / \mathrm{sec}$ for summer session

The maximum pressure inside the earth tube heat exchanger for summer session is $16.04 \mathrm{~Pa}$ has been recorded.

24) Computational fluid dynamics analysis for of earth tube heat exchanger using horizontal pipe at velocity of $5 \mathrm{~m} / \mathrm{sec}$ for winter session:

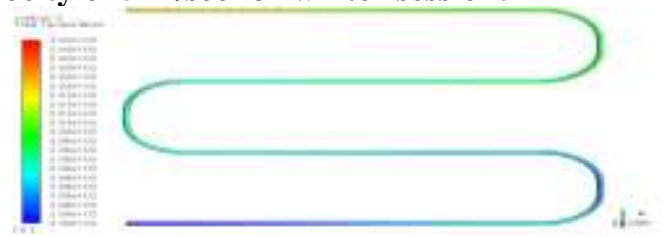

Figure 42: Temperature distribution inside the earth tube heat exchanger using horizontal pipe at velocity of $5 \mathrm{~m} / \mathrm{sec}$ for winter session 
The temperature increase from $288 \mathrm{~K}$ to $293 \mathrm{~K}$ has been recorded and the temperature difference of 5 degree has been observed.

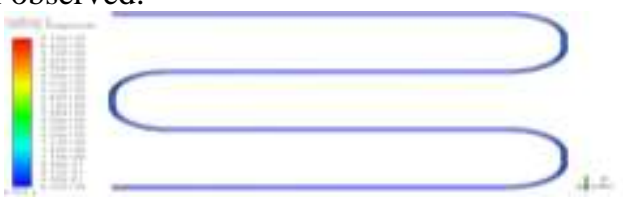

Figure 43: Velocity distribution inside the earth tube heat exchanger using horizontal pipe at velocity of $5 \mathrm{~m} / \mathrm{sec}$ for winter session

The maximum velocity of $5.73 \mathrm{~m} / \mathrm{sec}$ has been recorded.

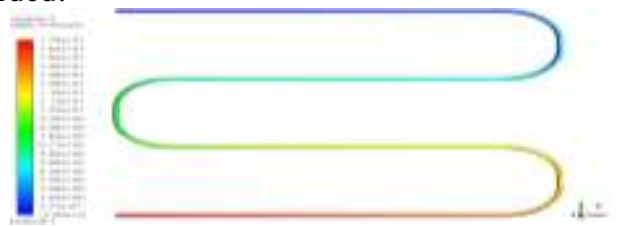

Figure 44: Pressure distribution inside the earth tube heat exchanger using horizontal pipe at velocity of $5 \mathrm{~m} / \mathrm{sec}$ for winter session

The maximum pressure inside the earth tube heat exchanger for summer session is $17 \mathrm{~Pa}$ has been recorded.

25) CFD analysis of Earth tube heat exchanger using vertical pipe

CAD Modeling:

In which the outer and inner diameters of the pipe are $80 \mathrm{~mm}$ and $78 \mathrm{~mm}$ respectively, and the total length of pipe is $50 \mathrm{~m}$. A two dimensional view of Earth tube heat exchanger using vertical pipe is shown in figure No.

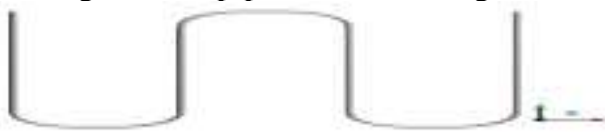

Figure 45: CAD geometry of earth tube heat exchanger using vertical pipe

26) Different boundaries of earth tube heat exchanger using vertical pipe:

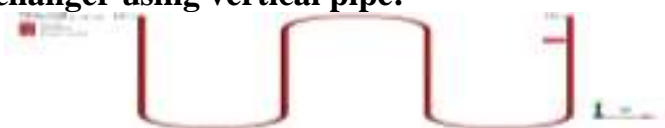

Figure 46: different boundaries of earth tube heat exchanger using vertical pipe

27) Computational fluid dynamics analysis for of earth tube heat exchanger using Vertical pipe at velocity of $0.5 \mathrm{~m} / \mathrm{sec}$ for summer session:

The temperature drop from $318 \mathrm{~K}$ to $296.7 \mathrm{~K}$ has been recorded and the temperature difference of 21.3 degree has been observed.
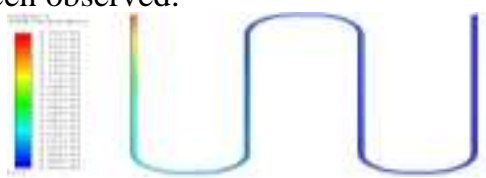

Figure 47 : Temperature distribution inside the earth tube heat exchanger using vertical pipe at velocity of $0.5 \mathrm{~m} / \mathrm{sec}$ for summer
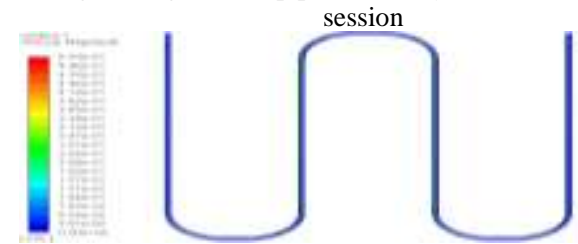

Figure 48: velocity distribution inside the earth tube heat exchange using vertical pipe at velocity of $0.5 \mathrm{~m} / \mathrm{sec}$ for summer session
The maximum velocity of $0.522 \mathrm{~m} / \mathrm{sec}$ has been recorded.
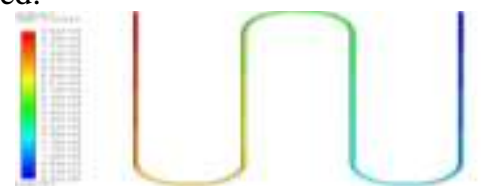

Figure 49: pressure distribution inside the earth tube heat exchanger using vertical pipe at velocity of $0.5 \mathrm{~m} / \mathrm{sec}$ for summer session

The maximum pressure inside the earth tube heat exchanger for summer session is $86332 \mathrm{~Pa}$ has been recorded.

28) Computational fluid dynamics analysis for of earth tube heat exchanger using vertical pipe at velocity of $0.5 \mathrm{~m} / \mathrm{sec}$ for winter session:
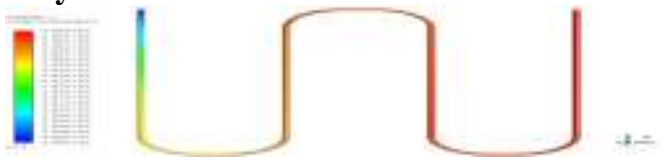

Figure 50: Temperature distribution inside the earth tube heat exchanger using vertical pipe at velocity of $0.5 \mathrm{~m} / \mathrm{sec}$ for winter session

The temperature increase from $288 \mathrm{~K}$ to $296.7 \mathrm{~K}$ has been recorded and the temperature difference of 8.7 degree has been observed.
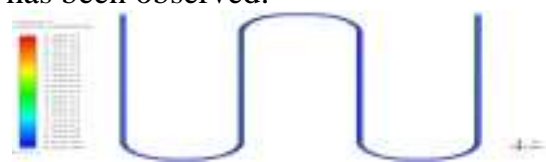

Figure 51: Velocity distribution inside the earth tube heat exchanger using vertical pipe at velocity of $0.5 \mathrm{~m} / \mathrm{sec}$ for winter session

The maximum velocity of $0.522 \mathrm{~m} / \mathrm{sec}$ has been recorded.

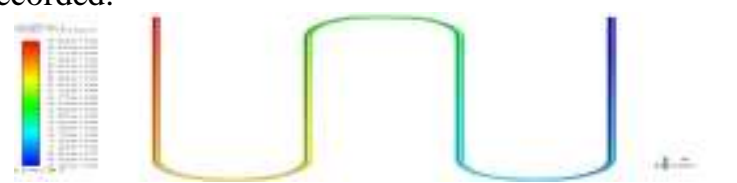

Figure 52: Pressure distribution inside the earth tube heat exchanger using vertical pipe at velocity of $0.5 \mathrm{~m} / \mathrm{sec}$ for winter session

The maximum pressure inside the earth tube heat exchanger for summer session is $86332 \mathrm{~Pa}$ has been recorded.

29) Computational fluid dynamics analysis for of earth tube heat exchanger using Vertical pipe at velocity of $1 \mathrm{~m} / \mathrm{sec}$ for summer session:

The temperature drop from $318 \mathrm{~K}$ to $297.9 \mathrm{~K}$ has been recorded and the temperature difference of 20.1 degree has been observed.
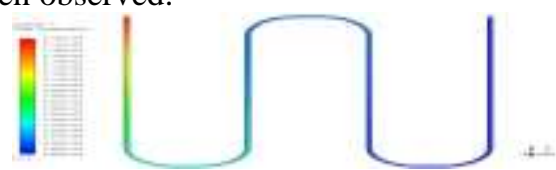

Figure 53: Temperature distribution inside the earth tube heat exchanger using vertical pipe at velocity of $1 \mathrm{~m} / \mathrm{sec}$ for summer

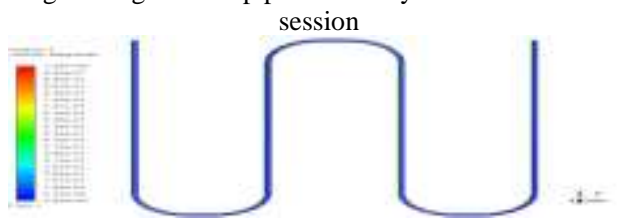

Figure 54: velocity distribution inside the earth tube heat exchanger using vertical pipe at velocity of $1 \mathrm{~m} / \mathrm{sec}$ for summer session The maximum velocity of $1.04 \mathrm{~m} / \mathrm{sec}$ has been recorded. 

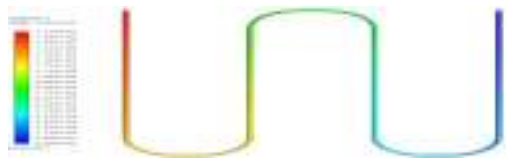

Figure 55: pressure distribution inside the earth tube heat exchanger using vertical pipe at velocity of $1 \mathrm{~m} / \mathrm{sec}$ for summer session

The maximum pressure inside the earth tube heat exchanger for summer session is $2 \mathrm{E}+5 \mathrm{~Pa}$ has been recorded.

30) Computational fluid dynamics analysis for of earth tube heat exchanger using vertical pipe at velocity of $1 \mathrm{~m} / \mathrm{sec}$ for winter session:

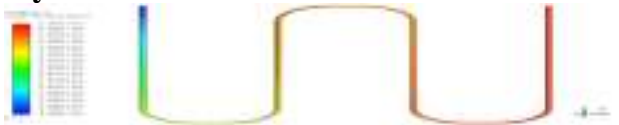

Figure 56: Temperature distribution inside the earth tube heat exchanger using vertical pipe at velocity of $1 \mathrm{~m} / \mathrm{sec}$ for winter session

The temperature increase from $288 \mathrm{~K}$ to $295.3 \mathrm{~K}$ has been recorded and the temperature difference of 7.3 degree has been observed.
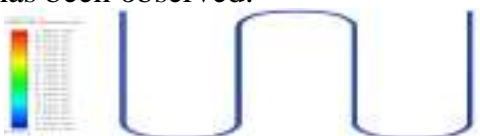

Figure 57: Velocity distribution inside the earth tube heat exchanger using vertical pipe at velocity of $1 \mathrm{~m} / \mathrm{sec}$ for winter session

The computational fluid dynamics analysis has been performed on earth tube heat exchanger using vertical pipe at velocity of $1 \mathrm{~m} / \mathrm{sec}$ for winter session, to get velocity distribution inside the earth tube heat exchanger. The maximum velocity of $1.043 \mathrm{~m} / \mathrm{sec}$ has been recorded.
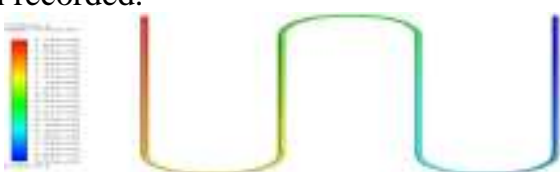

Figure 58: Pressure distribution inside the earth tube heat exchanger using vertical pipe at velocity of $1 \mathrm{~m} / \mathrm{sec}$ for winter session

The maximum pressure inside the earth tube heat exchanger for summer session is $2 \mathrm{E}+5 \mathrm{~Pa}$ has been recorded.

31) Computational fluid dynamics analysis for of earth tube heat exchanger using Vertical pipe at velocity of $2 \mathrm{~m} / \mathrm{sec}$ for summer session:

The computational fluid dynamics analysis has been performed on earth tube heat exchanger using vertical pipe at velocity of $2 \mathrm{~m} / \mathrm{sec}$ for summer session, to get temperature distribution inside the earth tube heat exchanger. The temperature drop from $318 \mathrm{~K}$ to $299.7 \mathrm{~K}$ has been recorded and the temperature difference of 18.3 degree has been observed.
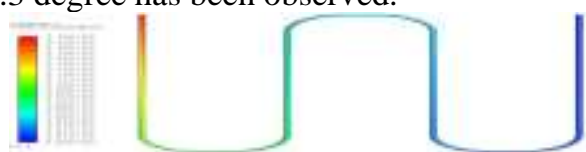

Figure 59: Temperature distribution inside the earth tube heat exchanger using vertical pipe at velocity of $2 \mathrm{~m} / \mathrm{sec}$ for summer
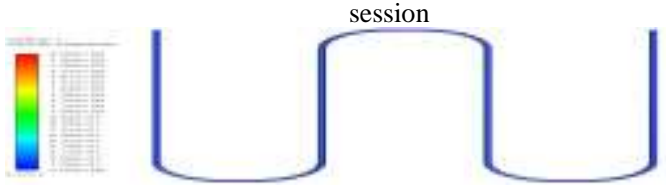

Figure 60: velocity distribution inside the earth tube heat exchanger using vertical pipe at velocity of $2 \mathrm{~m} / \mathrm{sec}$ for summer session

The maximum velocity of $2.089 \mathrm{~m} / \mathrm{sec}$ has been recorded.
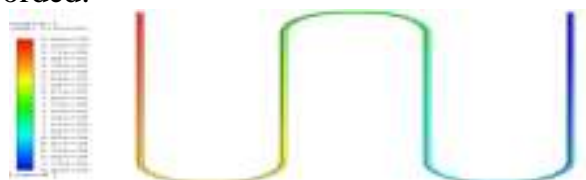

Figure 61: pressure distribution inside the earth tube heat exchange using vertical pipe at velocity of $2 \mathrm{~m} / \mathrm{sec}$ for summer session

The maximum pressure inside the earth tube heat exchanger for summer session is $3 \mathrm{E}+5 \mathrm{~Pa}$ has been recorded.

32) Computational fluid dynamics analysis for of earth tube heat exchanger using vertical pipe at velocity of $2 \mathrm{~m} / \mathrm{sec}$ for winter session:
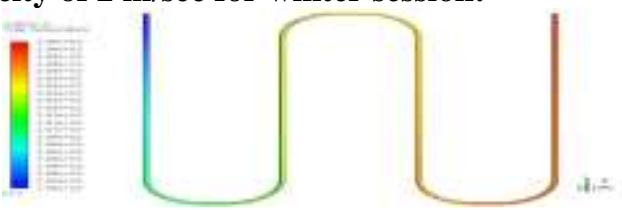

Figure 62: Temperature distribution inside the earth tube heat exchanger using vertical pipe at velocity of $2 \mathrm{~m} / \mathrm{sec}$ for winter session

The temperature increase from $288 \mathrm{~K}$ to $294.7 \mathrm{~K}$ has been recorded and the temperature difference of 6.7 degree has been observed.

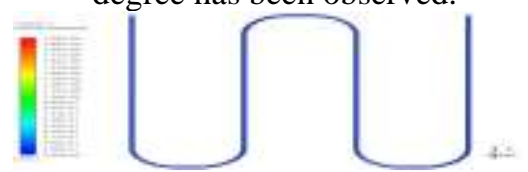

Figure 63: Velocity distribution inside the earth tube heat exchanger using vertical pipe at velocity of $2 \mathrm{~m} / \mathrm{sec}$ for winter session

The maximum velocity of $2.088 \mathrm{~m} / \mathrm{sec}$ has been recorded.
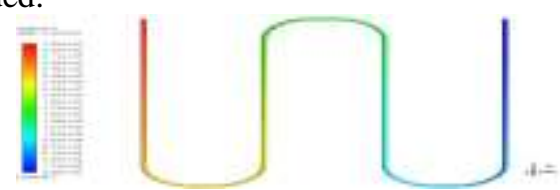

Figure64: Pressure distribution inside the earth tube heat exchanger using vertical pipe at velocity of $2 \mathrm{~m} / \mathrm{sec}$ for winter session

The maximum pressure inside the earth tube heat exchanger for summer session is $3 \mathrm{E}+5 \mathrm{~Pa}$ has been recorded.

33) Computational fluid dynamics analysis for of earth tube heat exchanger using Vertical pipe at velocity of $3 \mathrm{~m} / \mathrm{sec}$ for summer session:

The temperature drop from $318 \mathrm{~K}$ to $301.1 \mathrm{~K}$ has been recorded and the temperature difference of 16.9 degree has been observed.
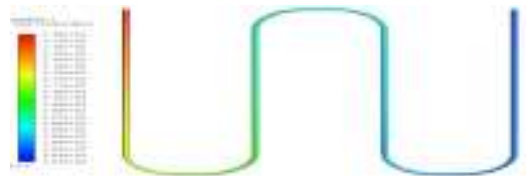

Figure 65: Temperature distribution inside the earth tube heat exchanger using vertical pipe at velocity of $3 \mathrm{~m} / \mathrm{sec}$ for summer

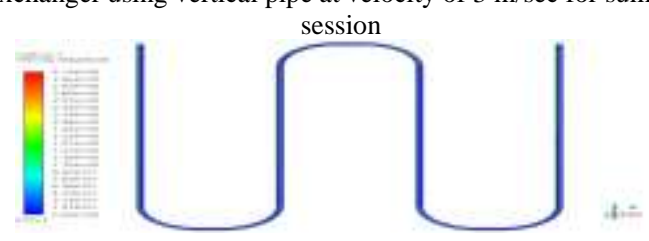


Figure66: velocity distribution inside the earth tube heat exchange using vertical pipe at velocity of $3 \mathrm{~m} / \mathrm{sec}$ for summer session

The maximum velocity of $3.13 \mathrm{~m} / \mathrm{sec}$ has been recorded.
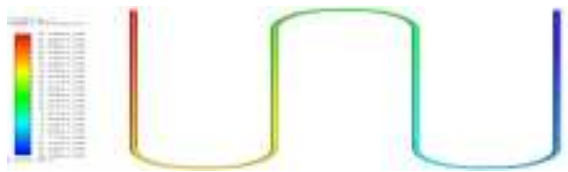

Figure67: pressure distribution inside the earth tube heat exchange using vertical pipe at velocity of $3 \mathrm{~m} / \mathrm{sec}$ for summer session

The maximum pressure inside the earth tube heat exchanger for summer session is $5 \mathrm{E}+5 \mathrm{~Pa}$ has been recorded.

34) Computational fluid dynamics analysis for of earth tube heat exchanger using vertical pipe at velocity of $3 \mathrm{~m} / \mathrm{sec}$ for winter session:

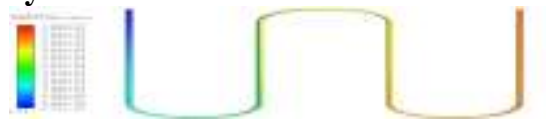

Figure68: Temperature distribution inside the earth tube heat exchanger using vertical pipe at velocity of $3 \mathrm{~m} / \mathrm{sec}$ for winter session

The temperature increase from $288 \mathrm{~K}$ to $294.2 \mathrm{~K}$ has been recorded and the temperature difference of 6.2 degree has been observed.
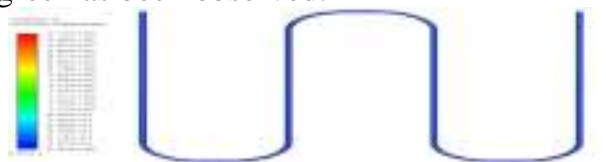

Figure69: Velocity distribution inside the earth tube heat exchanger using vertical pipe at velocity of $3 \mathrm{~m} / \mathrm{sec}$ for winter session

The maximum velocity of $3.14 \mathrm{~m} / \mathrm{sec}$ has been recorded.
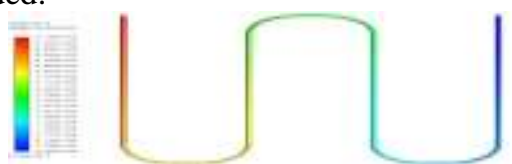

Figure70: Pressure distribution inside the earth tube heat exchange using vertical pipe at velocity of $3 \mathrm{~m} / \mathrm{sec}$ for winter session

The maximum pressure inside the earth tube heat exchanger for summer session is $2 \mathrm{E}+5 \mathrm{~Pa}$ has been recorded.

35) Computational fluid dynamics analysis for of earth tube heat exchanger using Vertical pipe at velocity of $4 \mathrm{~m} / \mathrm{sec}$ for summer session:

The temperature drop from $318 \mathrm{~K}$ to $302.5 \mathrm{~K}$ has been recorded and the temperature difference of 15.5 degree has been observed.
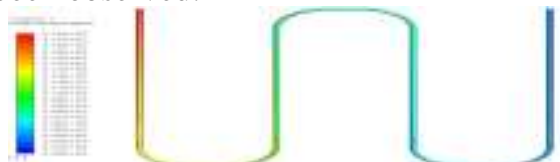

Figure 71: Temperature distribution inside the earth tube heat exchanger using vertical pipe at velocity of $4 \mathrm{~m} / \mathrm{sec}$ for summer
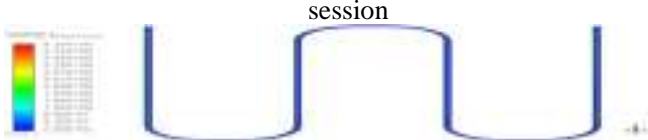

Figure 72: velocity distribution inside the earth tube heat exchanger using vertical pipe at velocity of $4 \mathrm{~m} / \mathrm{sec}$ for summer session

The maximum velocity of $4.18 \mathrm{~m} / \mathrm{sec}$ has been recorded.

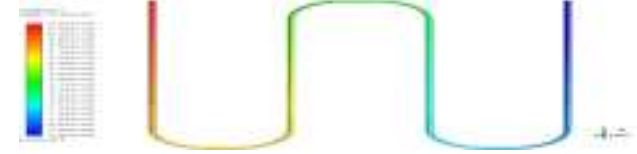

Figure73: pressure distribution inside the earth tube heat exchanger using vertical pipe at velocity of $4 \mathrm{~m} / \mathrm{sec}$ for summer session

The maximum pressure inside the earth tube heat exchanger for summer session is $7 \mathrm{E}+5 \mathrm{~Pa}$ has been recorded.

36) Computational fluid dynamics analysis for of earth tube heat exchanger using vertical pipe at velocity of $4 \mathrm{~m} / \mathrm{sec}$ for winter session:

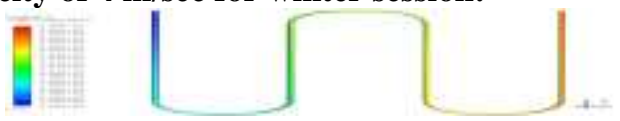

Figure 74: Temperature distribution inside the earth tube hea exchanger using vertical pipe at velocity of $4 \mathrm{~m} / \mathrm{sec}$ for winter session

The temperature increase from $288 \mathrm{~K}$ to $293.7 \mathrm{~K}$ has been recorded and the temperature difference of 5.7 degree has been observed.

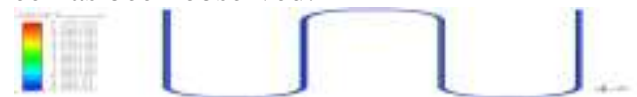

Figure75: Velocity distribution inside the earth tube heat exchanger using vertical pipe at velocity of $4 \mathrm{~m} / \mathrm{sec}$ for winter session

The maximum velocity of $4.176 \mathrm{~m} / \mathrm{sec}$ has been recorded.

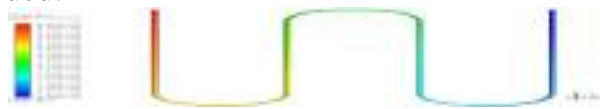

Figure76: Pressure distribution inside the earth tube heat exchanger using vertical pipe at velocity of $4 \mathrm{~m} / \mathrm{sec}$ for winter session

The maximum pressure inside the earth tube heat exchanger for summer session is $7 \mathrm{E}+5 \mathrm{~Pa}$ has been recorded.

37) Computational fluid dynamics analysis for of earth tube heat exchanger using Vertical pipe at velocity of $5 \mathrm{~m} / \mathrm{sec}$ for summer session:

The temperature drop from $318 \mathrm{~K}$ to $304 \mathrm{~K}$ has been recorded and the temperature difference of 14 degree has been observed.
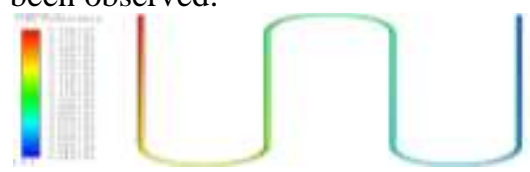

Figure 77: Temperature distribution inside the earth tube heat exchanger using vertical pipe at velocity of $5 \mathrm{~m} / \mathrm{sec}$ for summer

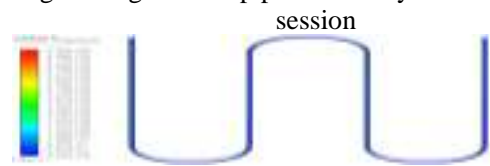

Figure 78: velocity distribution inside the earth tube heat exchanger using vertical pipe at velocity of $5 \mathrm{~m} / \mathrm{sec}$ for summer session

The maximum velocity of $5.22 \mathrm{~m} / \mathrm{sec}$ has been recorded.
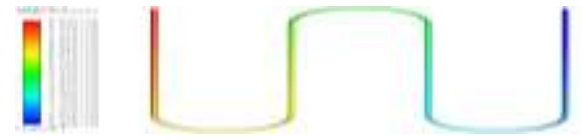

Figure79: pressure distribution inside the earth tube heat exchanger using vertical pipe at velocity of $5 \mathrm{~m} / \mathrm{sec}$ for summer session

The maximum pressure inside the earth tube heat exchanger for summer session is $9 \mathrm{E}+5 \mathrm{~Pa}$ has been recorded. 
38) Computational fluid dynamics analysis for of earth tube heat exchanger using vertical pipe at velocity of $5 \mathrm{~m} / \mathrm{sec}$ for winter session:

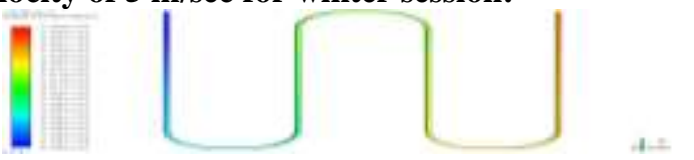

Figure 80: Temperature distribution inside the earth tube heat exchanger using vertical pipe at velocity of $5 \mathrm{~m} / \mathrm{sec}$ for winter session

The temperature increase from $288 \mathrm{~K}$ to $293 \mathrm{~K}$ has been recorded and the temperature difference of 5 degree has been observed.
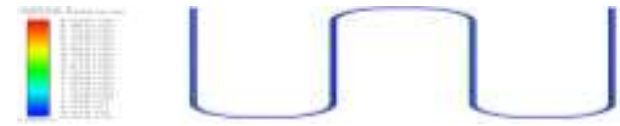

Figure 81: Velocity distribution inside the earth tube heat exchanger using vertical pipe at velocity of $5 \mathrm{~m} / \mathrm{sec}$ for winter session

The maximum velocity of $5.22 \mathrm{~m} / \mathrm{sec}$ has been recorded.
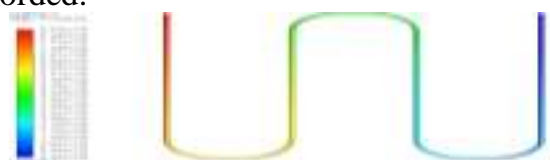

Figure 82: Pressure distribution inside the earth tube heat exchanger using vertical pipe at velocity of $5 \mathrm{~m} / \mathrm{sec}$ for winter session

The maximum pressure inside the earth tube heat exchanger for summer session is $9 \mathrm{E}+5 \mathrm{~Pa}$ has been recorded.

39) CFD analysis of Earth tube heat exchanger using inclined pipe

\section{CAD Modeling:}

In which the outer and inner diameters of the pipe are $80 \mathrm{~mm}$ and $78 \mathrm{~mm}$ respectively, and the total length of pipe is $50 \mathrm{~m}$. A two dimensional view of Earth tube heat exchanger using inclined pipe is shown in figure No.

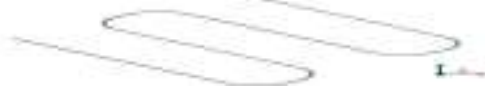

Figure 83: CAD geometry of earth tube heat exchanger using inclined pipe

40) Different boundaries of earth tube heat exchanger using inclined pipe:

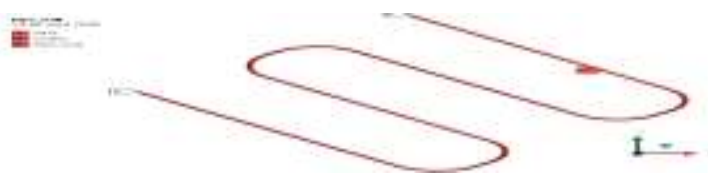

Figure 84: different boundaries of earth tube heat exchanger using inclined pipe

41) Computational fluid dynamics analysis for of earth tube heat exchanger using inclined pipe at velocity of $0.5 \mathrm{~m} / \mathrm{sec}$ for summer session:

The temperature drop from $318 \mathrm{~K}$ to $299.9 \mathrm{~K}$ has been recorded and the temperature difference of 18.1 degree has been observed.

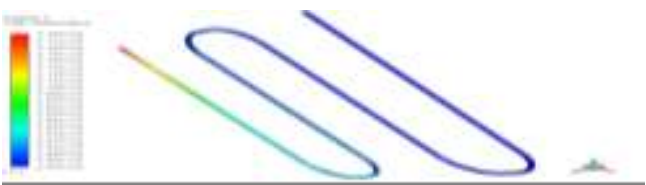

Figure 85: Temperature distribution inside the earth tube heat exchanger using Inclined pipe at velocity of $0.5 \mathrm{~m} / \mathrm{sec}$ for summer session

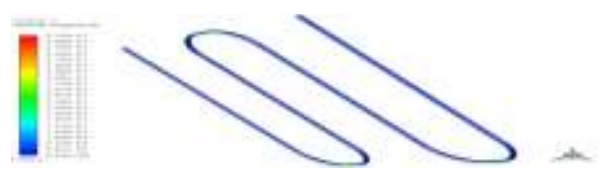

Figure 86: velocity distribution inside the earth tube heat exchanger using Inclined pipe at velocity of $0.5 \mathrm{~m} / \mathrm{sec}$ for summer session

The maximum velocity of $0.522 \mathrm{~m} / \mathrm{sec}$ has been recorded.

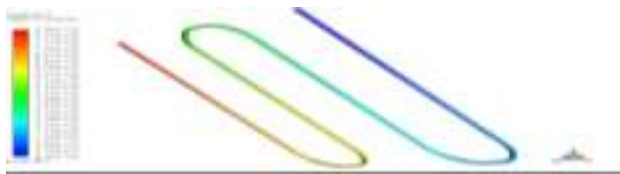

Figure 87: pressure distribution inside the earth tube heat exchanger using inclined pipe at velocity of $0.5 \mathrm{~m} / \mathrm{sec}$ for summer session The maximum pressure inside the earth tube heat exchanger for summer session is $86332 \mathrm{~Pa}$ has been recorded.

42) Computational fluid dynamics analysis for of earth tube heat exchanger using inclined pipe at velocity of $0.5 \mathrm{~m} / \mathrm{sec}$ for winter session:

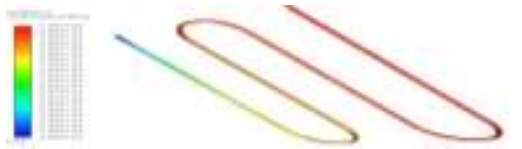

Figure 88: Temperature distribution inside the earth tube heat exchanger using inclined pipe at velocity of $0.5 \mathrm{~m} / \mathrm{sec}$ for winter session

The temperature increase from $288 \mathrm{~K}$ to $295.9 \mathrm{~K}$ has been recorded and the temperature difference of 7.9 degree has been observed.

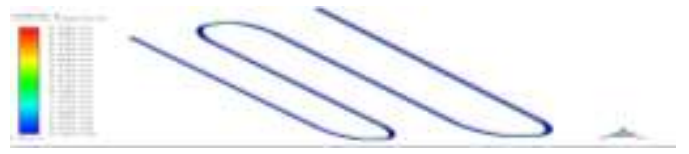

Figure 89 : Velocity distribution inside the earth tube heat exchanger using inclined pipe at velocity of $0.5 \mathrm{~m} / \mathrm{sec}$ for winter session

The maximum velocity of $0.522 \mathrm{~m} / \mathrm{sec}$ has been recorded.

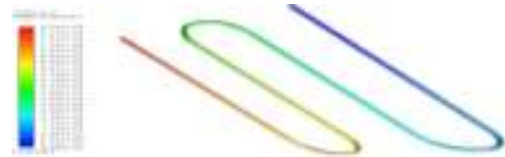

Figure 90: Pressure distribution inside the earth tube heat exchanger using inclined pipe at velocity of $0.5 \mathrm{~m} / \mathrm{sec}$ for winter session

The maximum pressure inside the earth tube heat exchanger for summer session is $86332 \mathrm{~Pa}$ has been recorded.

43) Computational fluid dynamics analysis for of earth tube heat exchanger using inclined pipe at velocity of $1 \mathrm{~m} / \mathrm{sec}$ for summer session:

The temperature drop from $318 \mathrm{~K}$ to $298.1 \mathrm{~K}$ has been recorded and the temperature difference of 19.9 degree has been observed. 

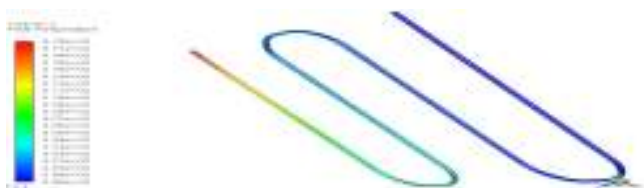

Figure 91:Temperature distribution inside the earth tube heat exchanger using Inclined pipe at velocity of $1 \mathrm{~m} / \mathrm{sec}$ for summer
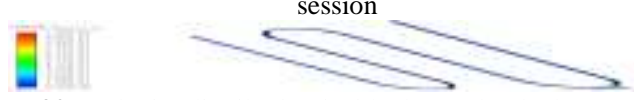

Figure 92 : velocity distribution inside the earth tube heat exchanger using Inclined pipe at velocity of $1 \mathrm{~m} / \mathrm{sec}$ for summer session

The maximum velocity of $1.045 \mathrm{~m} / \mathrm{sec}$ has been recorded.
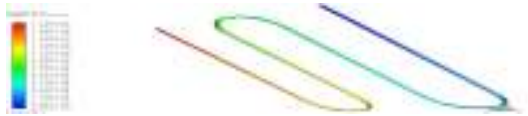

Figure 93: pressure distribution inside the earth tube heat exchanger using inclined pipe at velocity of $1 \mathrm{~m} / \mathrm{sec}$ for summer session

The maximum pressure inside the earth tube heat exchanger for summer session is $2 \mathrm{E}+5 \mathrm{~Pa}$ has been recorded.

44) Computational fluid dynamics analysis for of earth tube heat exchanger using inclined pipe at velocity of $1 \mathrm{~m} / \mathrm{sec}$ for winter session:
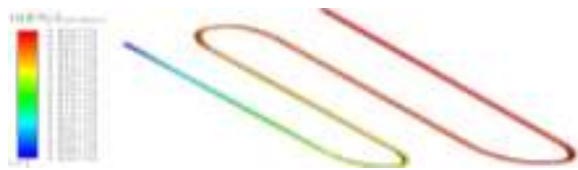

Figure 94: Temperature distribution inside the earth tube heat exchanger using inclined pipe at velocity of $1 \mathrm{~m} / \mathrm{sec}$ for winter session

The temperature increase from $288 \mathrm{~K}$ to $295.4 \mathrm{~K}$ has been recorded and the temperature difference of 7.4 degree has been observed.
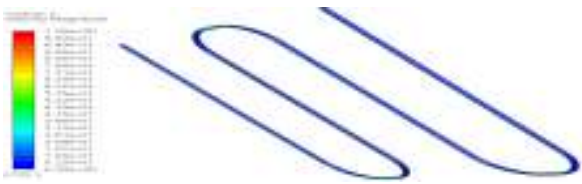

Figure 95: Velocity distribution inside the earth tube heat exchanger using inclined pipe at velocity of $1 \mathrm{~m} / \mathrm{sec}$ for winter session

The maximum velocity of $1.045 \mathrm{~m} / \mathrm{sec}$ has been recorded.

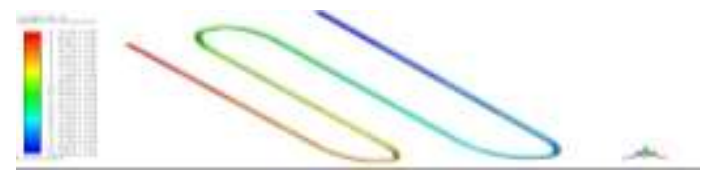

Figure 96 : Pressure distribution inside the earth tube heat exchanger using inclined pipe at velocity of $1 \mathrm{~m} / \mathrm{sec}$ for winter session

The maximum pressure inside the earth tube heat exchanger for summer session is $2 \mathrm{E}+5 \mathrm{~Pa}$ has been recorded.

45) Computational fluid dynamics analysis for of earth tube heat exchanger using inclined pipe at velocity of $\mathbf{2} \mathbf{~ m} / \mathbf{s e c}$ for summer session:

The temperature drop from $318 \mathrm{~K}$ to $299.9 \mathrm{~K}$ has been recorded and the temperature difference of 18.1 degree has been observed.

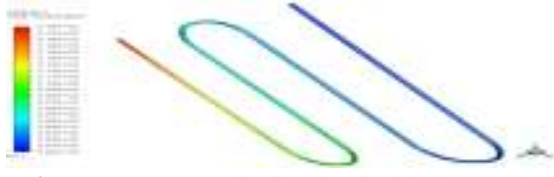

Figure 97: Temperature distribution inside the earth tube heat exchanger using Inclined pipe at velocity of $2 \mathrm{~m} / \mathrm{sec}$ for summer session
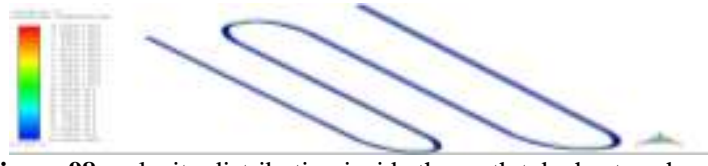

Figure 98: velocity distribution inside the earth tube heat exchange using Inclined pipe at velocity of $2 \mathrm{~m} / \mathrm{sec}$ for summer session

The maximum velocity of $2.089 \mathrm{~m} / \mathrm{sec}$ has been recorded.

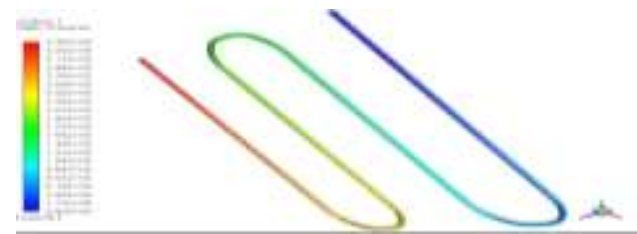

Figure 99: pressure distribution inside the earth tube heat exchanger using inclined pipe at velocity of $2 \mathrm{~m} / \mathrm{sec}$ for summer session

The maximum pressure inside the earth tube heat exchanger for summer session is $3 \mathrm{E}+5 \mathrm{~Pa}$ has been recorded.

46) Computational fluid dynamics analysis for of earth tube heat exchanger using inclined pipe at velocity of $2 \mathrm{~m} / \mathrm{sec}$ for winter session:

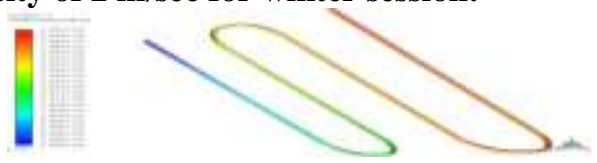

Figure100: Temperature distribution inside the earth tube heat exchanger using inclined pipe at velocity of $2 \mathrm{~m} / \mathrm{sec}$ for winter session

The temperature increase from $288 \mathrm{~K}$ to $293 \mathrm{~K}$ has been recorded and the temperature difference of 5 degree has been observed.

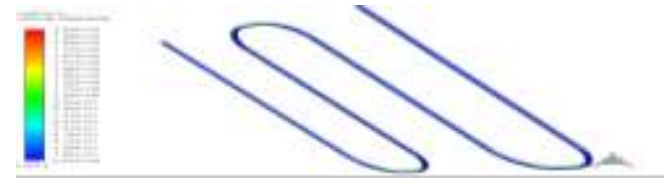

Figure101: Velocity distribution inside the earth tube heat exchanger using inclined pipe at velocity of $2 \mathrm{~m} / \mathrm{sec}$ for winter session

The maximum velocity of $2.089 \mathrm{~m} / \mathrm{sec}$ has been recorded.
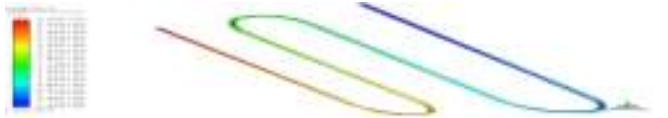

Figure102: Pressure distribution inside the earth tube heat exchanger using inclined pipe at velocity of $2 \mathrm{~m} / \mathrm{sec}$ for winter session

The maximum pressure inside the earth tube heat exchanger for summer session is $3 \mathrm{E}+5 \mathrm{~Pa}$ has been recorded.

47) Computational fluid dynamics analysis for of earth tube heat exchanger using inclined pipe at velocity of $3 \mathrm{~m} / \mathrm{sec}$ for summer session: 
The temperature drop from $318 \mathrm{~K}$ to $301.4 \mathrm{~K}$ has been recorded and the temperature difference of 16.6 degree has been observed.

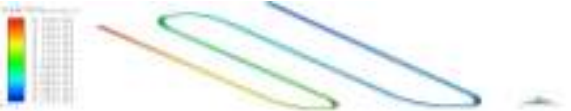

Figure 103: Temperature distribution inside the earth tube heat exchanger using Inclined pipe at velocity of $3 \mathrm{~m} / \mathrm{sec}$ for summer session

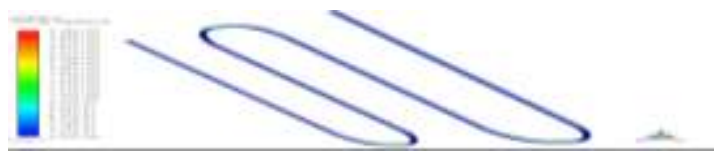

Figure 104: velocity distribution inside the earth tube heat exchanger using Inclined pipe at velocity of $3 \mathrm{~m} / \mathrm{sec}$ for summer session

The maximum velocity of $3.14 \mathrm{~m} / \mathrm{sec}$ has been recorded.

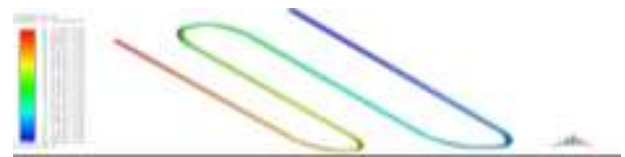

Figure105: pressure distribution inside the earth tube heat exchanger using inclined pipe at velocity of $3 \mathrm{~m} / \mathrm{sec}$ for summer session

The maximum pressure inside the earth tube heat exchanger for summer session is $5 \mathrm{E}+5 \mathrm{~Pa}$ has been recorded.

48) Computational fluid dynamics analysis for of earth tube heat exchanger using inclined pipe at velocity of $3 \mathrm{~m} / \mathrm{sec}$ for winter session:

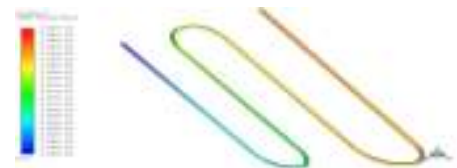

Figure106: Temperature distribution inside the earth tube heat exchanger using inclined pipe at velocity of $3 \mathrm{~m} / \mathrm{sec}$ for winter session

The temperature increase from $288 \mathrm{~K}$ to $294.2 \mathrm{~K}$ has been recorded and the temperature difference of 6.2 degree has been observed.
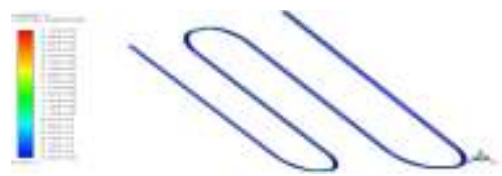

Figure107: Velocity distribution inside the earth tube heat exchanger using inclined pipe at velocity of $3 \mathrm{~m} / \mathrm{sec}$ for winter session

The maximum velocity of $3.14 \mathrm{~m} / \mathrm{sec}$ has been recorded.

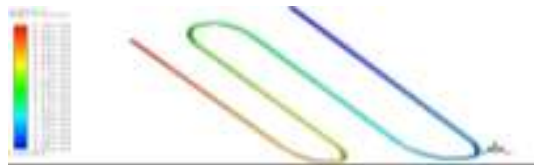

Figure108: Pressure distribution inside the earth tube heat exchanger using inclined pipe at velocity of $3 \mathrm{~m} / \mathrm{sec}$ for winter session

The maximum pressure inside the earth tube heat exchanger for summer session is $5 \mathrm{E}+5 \mathrm{~Pa}$ has been recorded.
49) Computational fluid dynamics analysis for of earth tube heat exchanger using inclined pipe at velocity of $\mathbf{4 ~ m} / \mathbf{s e c}$ for summer session:

The temperature drop from $318 \mathrm{~K}$ to $302.8 \mathrm{~K}$ has been recorded and the temperature difference of 15.2 degree has been observed.
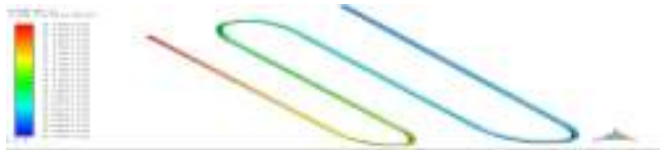

Figure 109: Temperature distribution inside the earth tube heat exchanger using Inclined pipe at velocity of $4 \mathrm{~m} / \mathrm{sec}$ for summer session

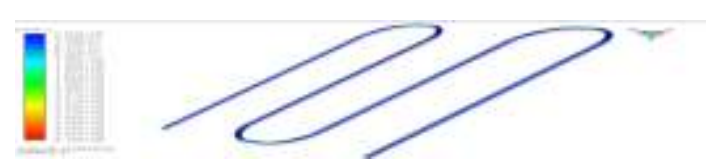

Figure 110: velocity distribution inside the earth tube heat exchanger using Inclined pipe at velocity of $4 \mathrm{~m} / \mathrm{sec}$ for summer session

The maximum velocity of $4.179 \mathrm{~m} / \mathrm{sec}$ has been recorded.

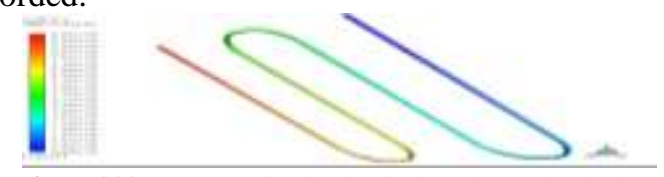

Figure111: pressure distribution inside the earth tube heat exchanger using inclined pipe at velocity of $4 \mathrm{~m} / \mathrm{sec}$ for summer session

The maximum pressure inside the earth tube heat exchanger for summer session is $7 \mathrm{E}+5 \mathrm{~Pa}$ has been recorded.

50) Computational fluid dynamics analysis for of earth tube heat exchanger using inclined pipe at velocity of $4 \mathrm{~m} / \mathrm{sec}$ for winter session:

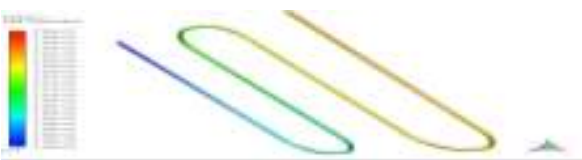

Figure112: Temperature distribution inside the earth tube heat exchanger using inclined pipe at velocity of $4 \mathrm{~m} / \mathrm{sec}$ for winter session

The temperature increase from $288 \mathrm{~K}$ to $293.7 \mathrm{~K}$ has been recorded and the temperature difference of 5.7 degree has been observed.

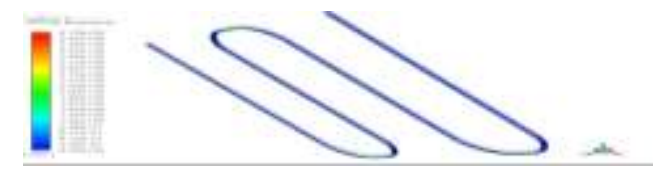

Figure113: Velocity distribution inside the earth tube heat exchanger using inclined pipe at velocity of $4 \mathrm{~m} / \mathrm{sec}$ for winter session

The maximum velocity of $4.18 \mathrm{~m} / \mathrm{sec}$ has been recorded.

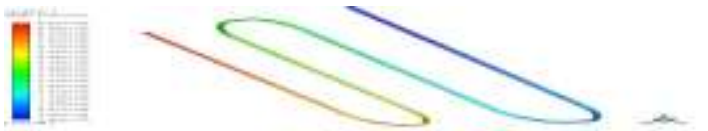

Figure114: Pressure distribution inside the earth tube heat exchanger using inclined pipe at velocity of $4 \mathrm{~m} / \mathrm{sec}$ for winter session 
The maximum pressure inside the earth tube heat exchanger for summer session is $7 \mathrm{E}+5 \mathrm{~Pa}$ has been recorded.

51) Computational fluid dynamics analysis for of earth tube heat exchanger using inclined pipe at velocity of $5 \mathbf{~ m} / \mathbf{s e c}$ for summer session:

The temperature drop from $318 \mathrm{~K}$ to $304 \mathrm{~K}$ has been recorded and the temperature difference of 14 degree has been observed.

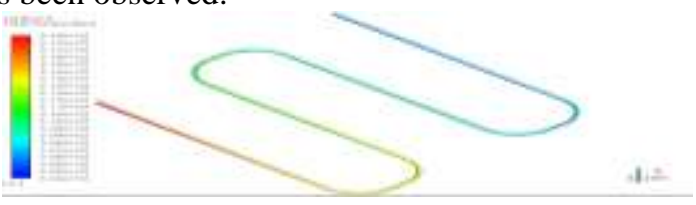

Figure 115: Temperature distribution inside the earth tube heat exchanger using Inclined pipe at velocity of $5 \mathrm{~m} / \mathrm{sec}$ for summe

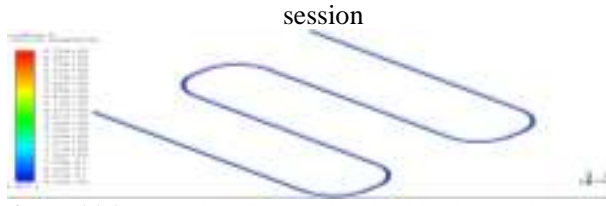

Figure116 : velocity distribution inside the earth tube heat exchanger using Inclined pipe at velocity of $5 \mathrm{~m} / \mathrm{sec}$ for summer session

The maximum velocity of $5.22 \mathrm{~m} / \mathrm{sec}$ has been recorded.

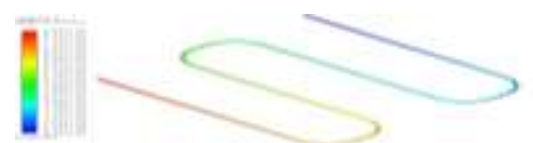

Figure117: pressure distribution inside the earth tube heat exchanger using inclined pipe at velocity of $5 \mathrm{~m} / \mathrm{sec}$ for summe session

The maximum pressure inside the earth tube heat exchanger for summer session is $9 \mathrm{E}+5 \mathrm{~Pa}$ has been recorded.

52) Computational fluid dynamics analysis for of earth tube heat exchanger using inclined pipe at velocity of $5 \mathrm{~m} / \mathrm{sec}$ for winter session:

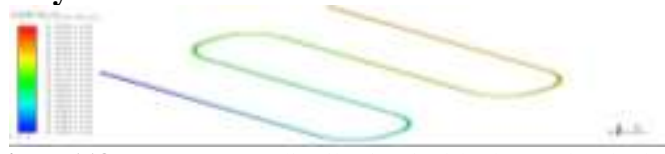

Figure118: Temperature distribution inside the earth tube heat exchanger using inclined pipe at velocity of $5 \mathrm{~m} / \mathrm{sec}$ for winter session

The temperature increase from $288 \mathrm{~K}$ to $293 \mathrm{~K}$ has been recorded and the temperature difference of 5 degree has been observed.

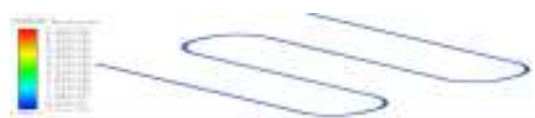

Figure119: Velocity distribution inside the earth tube heat exchanger using inclined pipe at velocity of $5 \mathrm{~m} / \mathrm{sec}$ for winter session

The maximum velocity of $5.22 \mathrm{~m} / \mathrm{sec}$ has been recorded.

Figure120: Pressure distribution inside the earth tube heat exchanger using inclined pipe at velocity of $5 \mathrm{~m} / \mathrm{sec}$ for winter session
The maximum pressure inside the earth tube heat exchanger for summer session is $9 \mathrm{E}+5 \mathrm{~Pa}$ has been recorded.
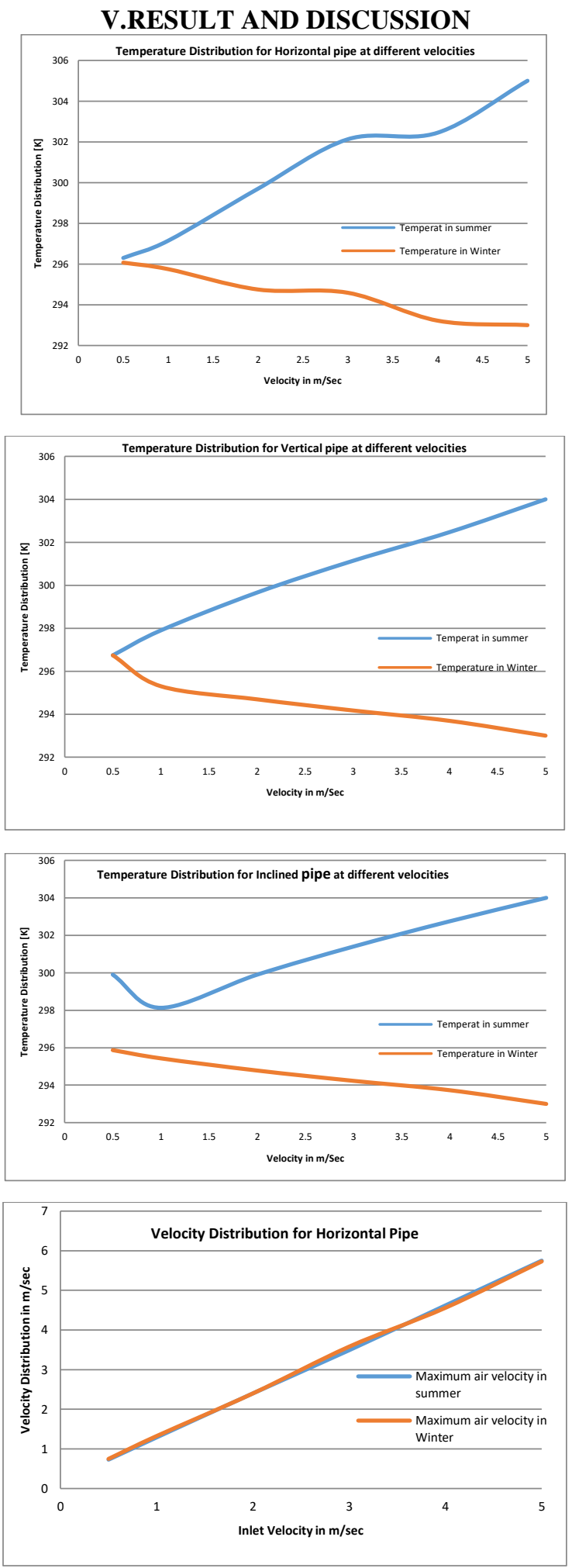

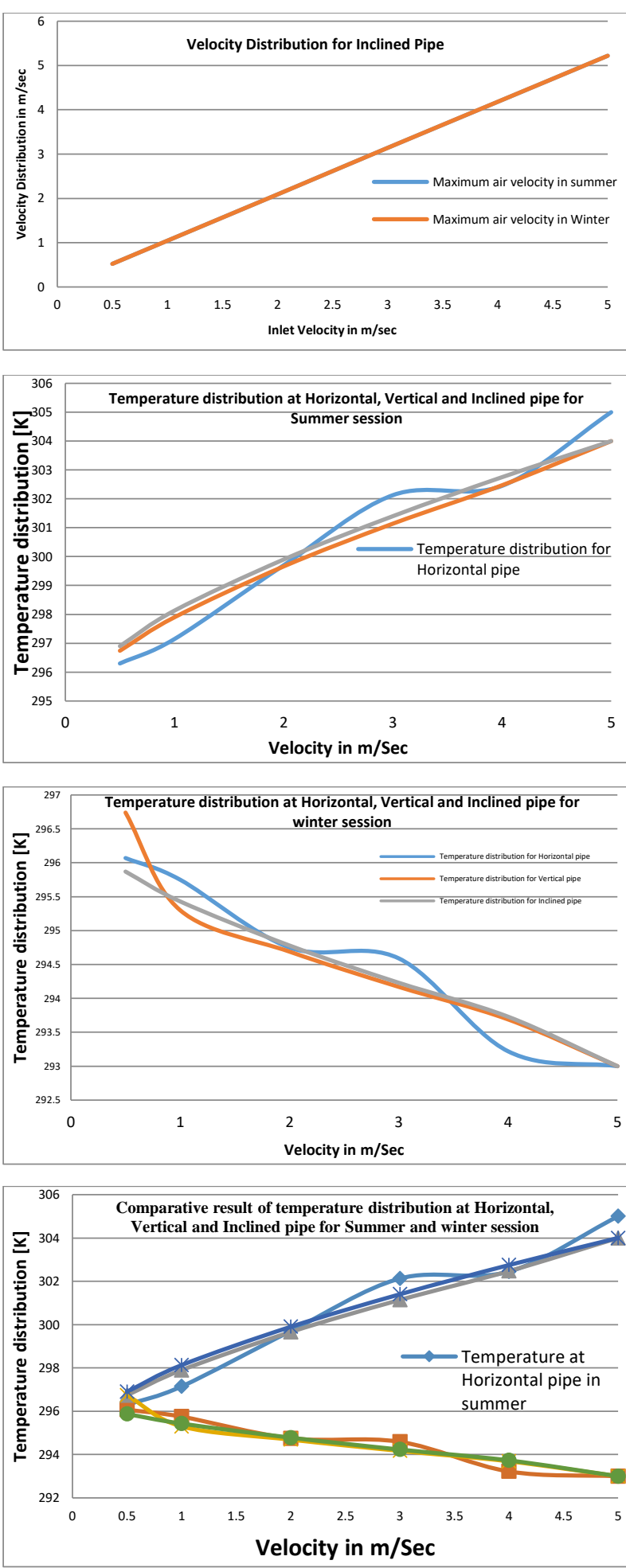

\section{VI.CONCLUSION AND FUTURE WORK}

In the present work computational fluid dynamics analysis have been performed at three different designs of earth tube heat exchanger for summer and winter session for Bhopal location to get thermal comfort inside the room and compared the results. There are following conclusive points drawn from this work.

1. After performing computational fluid dynamics analysis on earth tube heat exchanger using horizontal pipe at various air velocity such as
$0.5 \mathrm{~m} / \mathrm{sec}, 1 \mathrm{~m} / \mathrm{sec}, 2 \mathrm{~m} / \mathrm{sec}, 3 \mathrm{~m} / \mathrm{sec}, 4 \mathrm{~m} / \mathrm{sec} \&$ $5 \mathrm{~m} / \mathrm{sec}$ for summer session, to get temperature distribution inside the earth tube heat exchanger. The temperature drop for all above air velocities are 296.3K, 297.1K, 299.7K, 302.1K, 302.5K \& 305K and the maximum temperature difference of 22 degree has been observed.

2. After performing computational fluid dynamics analysis on earth tube heat exchanger using horizontal pipe at various air velocity such as $0.5 \mathrm{~m} / \mathrm{sec}, 1 \mathrm{~m} / \mathrm{sec}, 2 \mathrm{~m} / \mathrm{sec}, 3 \mathrm{~m} / \mathrm{sec}, 4 \mathrm{~m} / \mathrm{sec} \&$ $5 \mathrm{~m} / \mathrm{sec}$ for winter session, to get temperature distribution inside the earth tube heat exchanger. The temperature drop for all above air velocities are 296.1K, 295.8K, 294.8K, 294.6K, 293.2K \& 293K and the maximum temperature difference of 8.01 degree has been observed.

3. After performing computational fluid dynamics analysis on earth tube heat exchanger using vertical pipe at various air velocity such as $0.5 \mathrm{~m} / \mathrm{sec}, 1$ $\mathrm{m} / \mathrm{sec}, 2 \mathrm{~m} / \mathrm{sec}, 3 \mathrm{~m} / \mathrm{sec}, 4 \mathrm{~m} / \mathrm{sec} \& 5 \mathrm{~m} / \mathrm{sec}$ for summer session, to get temperature distribution inside the earth tube heat exchanger. The temperature drop for all above air velocities are 296.7K, 297.9K, 299.9K, 301.1K, 302.5K \& 304K and the maximum temperature difference of 22 degree has been observed.

4. After performing computational fluid dynamics analysis on earth tube heat exchanger using vertical pipe at various air velocity such as $0.5 \mathrm{~m} / \mathrm{sec}, 1$ $\mathrm{m} / \mathrm{sec}, 2 \mathrm{~m} / \mathrm{sec}, 3 \mathrm{~m} / \mathrm{sec}, 4 \mathrm{~m} / \mathrm{sec} \& 5 \mathrm{~m} / \mathrm{sec}$ for winter session, to get temperature distribution inside the earth tube heat exchanger. The temperature drop for all above air velocities are $296.7 \mathrm{~K}, 295.3 \mathrm{~K}, 294.7 \mathrm{~K}$, $294.2 \mathrm{~K}, 293.7 \mathrm{~K} \& 293 \mathrm{~K}$ and the maximum temperature difference of 22 degree has been observed.

5. After performing computational fluid dynamics analysis on earth tube heat exchanger using inclined pipe at various air velocity such as $0.5 \mathrm{~m} / \mathrm{sec}, 1$ $\mathrm{m} / \mathrm{sec}, 2 \mathrm{~m} / \mathrm{sec}, 3 \mathrm{~m} / \mathrm{sec}, 4 \mathrm{~m} / \mathrm{sec} \& 5 \mathrm{~m} / \mathrm{sec}$ for summer session, to get temperature distribution inside the earth tube heat exchanger. The temperature drop for all above air velocities are 299.9K, 298.1K, 299.9K, 301.4K, 302.8K \& 304K and the maximum temperature difference of 22 degree has been observed.

6. After performing computational fluid dynamics analysis on earth tube heat exchanger using inclined pipe at various air velocity such as $0.5 \mathrm{~m} / \mathrm{sec}, 1$ $\mathrm{m} / \mathrm{sec}, 2 \mathrm{~m} / \mathrm{sec}, 3 \mathrm{~m} / \mathrm{sec}, 4 \mathrm{~m} / \mathrm{sec} \& 5 \mathrm{~m} / \mathrm{sec}$ for winter session, to get temperature distribution inside the earth tube heat exchanger. The temperature drop for all above air velocities are $295.9 \mathrm{~K}, 295.4 \mathrm{~K}, 294.8 \mathrm{~K}$, $294.2 \mathrm{~K}, 293.7 \& 293 \mathrm{~K}$ and the maximum temperature difference of 22 degree has been observed.

It has been observed from the results of computational fluid dynamic analysis that the earth tube heat exchanger using horizontal pipe gives better result as 
compared with vertical and inclined piping arrangement. So it is recommended that the earth tube heat exchanger using horizontal pipe arrangement may be used for better thermal comfort.

\section{Future scope:}

The main aim of present work to investigate the arrangements of piping system of earth tube heat exchanger for better thermal comfort. For these work CFD analysis on three different designs of earth tube heat exchanger for summer and winter session for Bhopal location have been performed. Though the study is performed with an utmost care then also there is scope for further improvement. Some of the suggestions for future study might be possible are explained.

1. In the present work CFD analysis are performed on three different designs of earth tube heat exchanger for summer and winter session but some other designs may also be used for future improvement.

2. In the present work CFD analysis of earth tube heat exchanger for summer and winter session are performed on fixed dimension but for future work variable dimensions may also be used.

3. In the present work temperature \& velocity distribution have been studies but some other parameters may also used to study for future improvement.

\section{REFERENCES}

[1] S. H. Hammadi "Tempering of Water Storage Tank Temperature in Hot Climates Regions Using Earth Water Heat Exchanger" Thermal Science and Engineering Progress, Accepted Date: 25 March 2018. https://doi.org/10.1016/j.tsep.2018.03.009.

[2] Namrata Bordoloi at el. "An intense review on the latest advancements of Earth Air Heat Exchangers" Renewable and Sustainable Energy Reviews, 89 (2018) 261-280.

[3] Sayeh Menhoudj at el "Study of the energy performance of an earth-Air heat exchanger for refreshing buildings in Algeria" Energy and Buildings 158 (2018) 1602-1612.

[4] Lazaros Aresti, Paul Christodoulidesb \& Georgios Florides "A review of the design aspects of ground heat exchangers" Renewable and Sustainable Energy Reviews 92 (2018) 757 773.

[5] Hassen Boughanmi, Mariem Lazaar \& Amenallah Guizani [5] A performance of a heat pump system connected a new conic helicoidal geothermal heat exchanger for a greenhouse heating in the north of Tunisia, Solar Energy 171 (2018) 343-353.

[6] Jiajia Gao at el. "Ground heat exchangers: Applications, technology integration and potentials for zero energy buildings" Renewable Energy 128 (2018) 337e349.

[7] Shabnam Gharibi at el. "Feasibility study of geothermal heat extraction from abandoned oil wells using a U-tube heat exchanger" Energy (2018), doi: 10.1016/j.energy.2018.04.003.

[8] Changhee Lee, Jangyoul You \& Hyeonku Park "In-situ response test of various borehole depths and heat injection rates at Standing Column Well geothermal heat exchanger systems" Energy \& Buildings Accepted date: 7 May 2018, doi: 10.1016/j.enbuild.2018.05.009. 